\title{
The Sustainability of Hunger Relief: Analysis of Emergency Food Providers in Low Access Counties of West Virginia
}

Juston Chad Morrison

West Virginia University

Follow this and additional works at: https://researchrepository.wvu.edu/etd

\section{Recommended Citation}

Morrison, Juston Chad, "The Sustainability of Hunger Relief: Analysis of Emergency Food Providers in Low Access Counties of West Virginia" (2011). Graduate Theses, Dissertations, and Problem Reports. 762.

https://researchrepository.wvu.edu/etd/762

This Thesis is protected by copyright and/or related rights. It has been brought to you by the The Research Repository @ WVU with permission from the rights-holder(s). You are free to use this Thesis in any way that is permitted by the copyright and related rights legislation that applies to your use. For other uses you must obtain permission from the rights-holder(s) directly, unless additional rights are indicated by a Creative Commons license in the record and/ or on the work itself. This Thesis has been accepted for inclusion in WVU Graduate Theses, Dissertations, and Problem Reports collection by an authorized administrator of The Research Repository @ WVU. For more information, please contact researchrepository@mail.wvu.edu. 


\title{
The Sustainability of Hunger Relief: Analysis of Emergency Food Providers in Low Access Counties of West Virginia
}

\author{
By Juston Chad Morrison
}
Thesis submitted to the Eberly College of Arts \& Sciences
at
West Virginia University
in partial fulfillment of the requirements
for the degree of
Master of Arts
in
Sociology
Lawrence Nichols, Ph.D Chair
Ronald Althouse, Ph.D
Jennifer Steele, Ph.D

Morgantown, WV 2011

Keywords: hunger, emergency food providers, food deserts 


\section{ABSTRACT \\ The Sustainability of Hunger Relief: Analysis of Emergency Food Providers in Low Access Counties of West Virginia}

\section{Juston Chad Morrison}

Hunger in West Virginia has long been considered a problem that stems from high poverty rates and rural low access communities. The purpose of this study is to assess the stability of emergency food providers in economically distressed counties in West Virginia. Data was collected from Clay and Webster counties, of which Clay is considered low access and Webster is severely low access or a food desert. Administrators of emergency food providers were asked to complete a questionnaire regarding basic information about their program, changes in client usage, and possible threats to the existence of their program. The questionnaires were followed up with in-person interviews to collect more information and expand on the results of the questionnaires.

The results showed that $83 \%$ of programs in Clay County and $100 \%$ of programs in Webster County face one or more problems that could threaten their existence. This compares to a national average of $67 \%$. The two largest concerns for programs include access to food and funding for the operations. Overall, this study has provided important information that can be used towards further projects on food access gaps. The research can be used as an outline for creating strategic partnerships between various agents of the food sector in West Virginia to address the root causes of hunger and develop new solutions. 


\section{Table of Contents}

Abstract $\quad$ ii

Table of Contents $\quad$ iii

List of Tables $\quad$ iv

$\begin{array}{ll}\text { Introduction } & 1\end{array}$

Literature Review 3

Methods of Data Collection and Analysis........................................................... 12

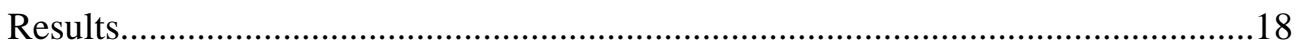

1. Profiles of Agencies and Feeding Programs................................................... 18

1.1 Participating Agencies and Programs.................................................. 18

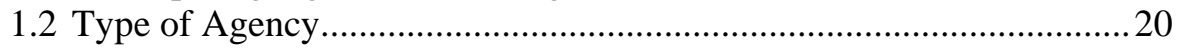

1.3 Length of Operation............................................................................ 21

1.4 Other Services in Addition to Food....................................................22

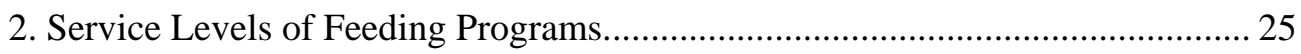

2.1 Number of Different People Served ...................................................25

2.2 Amount of Meals/Boxes Distributed in Week.......................................27

2.3 Agency Estimates of Change in the Number of Clients.........................28

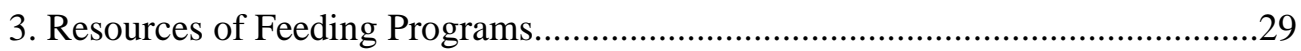

3.1 Sources of Food Distributed by Program...............................................29

3.2 Paid Staff and Volunteer Resources....................................................... 30

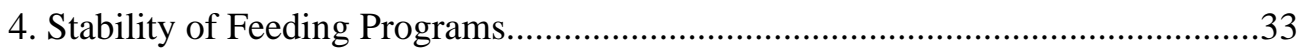

4.1 Problems that Threaten the Programs...........................................................33

4.2 Frequency of Stretching Food Resources...............................................42

4.3 Programs that Turned Clients Away......................................................46

4.4 Additional Resource Needed.................................................................52

4.5 Impact of Elimination of Food Bank.....................................................57

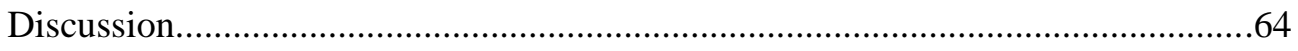

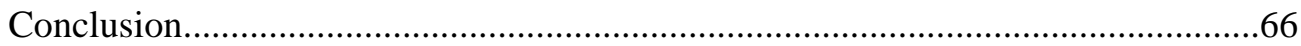

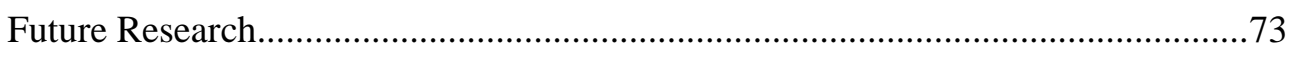

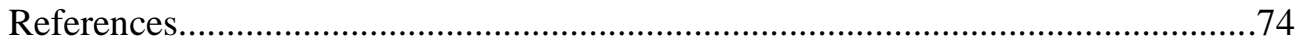

Appendix 1- Map of Distressed Counties...............................................................77

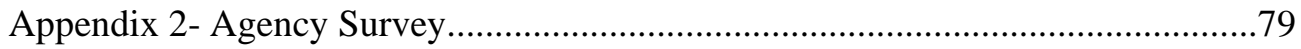




\section{List of Tables}

Table 1.1.1: $\quad$ Programs Reported on by Participating Agencies by Program Type........................19 (Clay and Webster County)

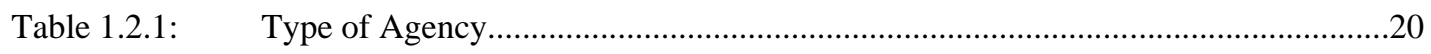

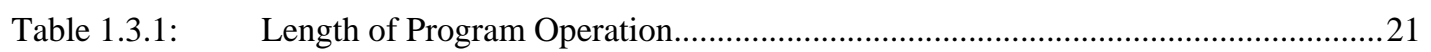

Table 1.4.1: $\quad$ Other Services or Programs Provided in Addition to Food Distribution...................23

Table 2.1.1: $\quad$ Amount of Different People or Different Households Served by the Food..............25 Program Between January 1, 2009 and December 31, 2009

Table 2.2.1: $\quad$ Amount of Meals or Bags/Boxes Distributed During a Typical Week................... 27

Table 2.3.1: $\quad$ Agency Estimates of Changes in Number of Clients from 2007-2010.................... 28

Table 3.1.1: Sources of Food Distributed by Program................................................................ 29

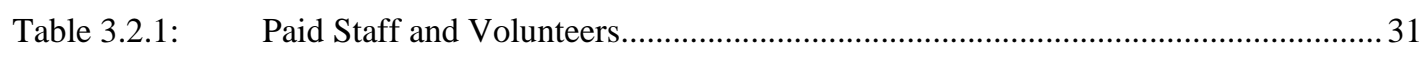

Table 4.1.1: $\quad$ Problems that Threaten Existence of Pantries........................................................ 34

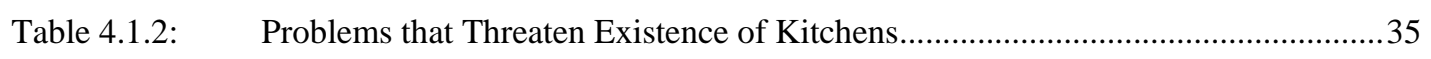

Table 4.1.3: Problems that Threaten Existence of All Programs in Clay or Webster....................36

Table 4.2.1: $\quad$ Frequency of Stretching Food Resources in Pantries................................................. 42

Table 4.2.2: $\quad$ Frequency of Stretching Food Resources in Kitchens............................................... 43

Table 4.2.3: Frequency of Stretching Food Resources in All Programs in Clay or Webster.......44

Table 4.3.1: $\quad$ Pantries that Turned Clients Away.............................................................................. 46

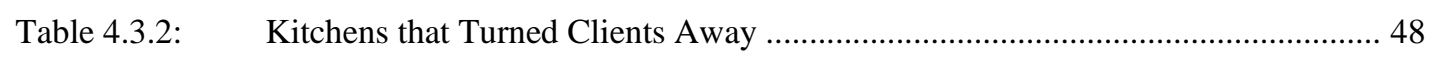

Table 4.3.3: All Programs that Turned Clients Away....................................................................49

Table 4.4.1: $\quad$ Additional Food Resources Needed per Week for Pantries...................................... 52

Table 4.4.2: $\quad$ Additional Food Resources Needed per Week for Kitchens.......................................53

Table 4.4.3: $\quad$ Additional Food Resources Needed per Week for All Programs...............................54 in Clay and Webster

Table 4.5.1: Impact of Elimination of Food Bank on Pantries..................................................... 57

Table 4.5.2: $\quad$ Impact of Elimination of Food Bank on Kitchens......................................................58

Table 4.5.3 Impact of Elimination of Food Bank on All Programs............................................59 


\section{Introduction}

Hunger in West Virginia has long been considered a problem that stems from high poverty rates and rural low food access communities. Recent research by the U.S. Department of Agriculture (USDA) finds that over 308,000 people in West Virginia live in poverty, putting them at an increased risk of hunger (USDA 2008). Private institutions have established emergency food programs to alleviate hunger, but national studies on the stability of these programs show that they face certain limitations. According to a study by Feeding America, 67\% of pantries, 67\% of kitchens, and 73\% of shelters believe they are facing one or more problems that threaten their existence (Cohen et al 2010). Cohen et al. (2010) found that the biggest threat to those programs was access to adequate funding, and low food resources a close second. The 2010 study performed by Feeding America left out all but seven of the fifty-five counties in West Virginia, leaving a gap in the research. The purpose of this research is to assess the stability of emergency food providers in low access economically distressed counties in West Virginia.

Since 1993, Feeding America, formerly America’s Second Harvest, has conducted a study on domestic hunger in the United States. Their study includes face-toface client interviews and surveys of local charitable agencies. Only in 2010 were seven counties from West Virginia included in the study. This study examines the food providers in two counties not included in the Feeding America study. The two sample counties, Webster and Clay, were chosen because both counties faced severe struggles economically and both had low access to food. Webster County represents a severe food desert in our study, a county where all the residents must travel 10 or more miles to access a large supermarket or food retailer. 
This study focuses primarily on the stability of the emergency food providers and not the clients themselves. Administrators of food providers were asked to answer questions in a survey regarding client usage, food access channels, and threats to the programs' existence. The surveys were followed up with face-to-face interviews to expand on the results of the survey and to get a better understanding of the daily struggles program face.

This study compares the results of the surveys with those from the Feeding America study to gain a perspective of where rural West Virginia counties reside in the national picture. Comparisons between low food access and severely low food access will also be presented to understand what, if any, differences exist among them. Finally, the research looks at some of the possible solutions that could be used to address hunger and some of the potential concepts that can be looked at for future projects on hunger in West Virginia. 


\section{Literature Review}

Food Insecurity and Hunger in the United States

Much of the research performed on food insecurity and hunger in the United States has focused on those individuals at-risk of being food insecure, or the problems that lead to individuals being at-risk. Household food insecurity and poverty levels have been extensively researched by the government's USDA and Food Nutrition Service (FNS). The concept of food security first appeared in international development work in the 1960s and 1970s as the ability to meet aggregate food needs in a consistent way (Anderson and Cook 1999). Food security is defined by the USDA as having access to enough food for an active healthy living for all household members (Nord and Andrews 2003). Households that do not have access to food because they lack money or other resources are labeled food insecure. Current research shows that 14.6\% (17 million households) of the population of the United States were food insecure as recent as 2008, up from 11.1 percent in 2007 (Nord et al. 2009).

Food insecurity and hunger are often used interchangeably, but represent different levels of gravity. Hunger is defined as the uneasy or painful sensation caused by the lack of food (Alaimo et al. 1998). Most research concentrates on food insecurity, because identifying hunger is so difficult. The understanding of hunger in the United States advanced significantly in the 1980s, when the constructs of food insecurity and food insufficiency were advanced as a proxy for the construct of hunger (Kleinman et al. 2009). Until 2006, the government measured food insecurity with two measures: food insecure and food insecure with hunger. Current studies use a four-tiered index to measure food security: high, marginal, low and very low. Recent reports show that 5.7\% 
of the U.S. population falls into the very low food security category, the most severe category (Nord et al. 2009).

A recent study on clients who receive emergency food services found that $78 \%$ of client households had an income of $130 \%$ or below the federal poverty line for the previous month (Cohen et al. 2010). Of these clients, 70\% were food insecure, with 33\% showing signs of hunger (Cohen et al. 2010).

Past research has linked food insecurity to psychosocial and health problems. Alaimo et al. (2002) found that food insecurity is positively associated with depression. For example, individuals are embarrassed by not being able to provide for themselves or their families. Children that experience food insecurity are at severe risk of developing learning and social disabilities. Children experiencing hunger are seven times more likely than those that are not to show signs of clinical dysfunction (Kleinman et al. 2009).

Obesity and other obesity-related chronic problems often stem from food insecurity because individuals are often unable to access the proper type of food. The West Virginia youth, in particular, have the second highest rate of obesity (20.9\%) in the United States (Singh et al. 2008). Webber (2007) studied two rural West Virginia counties and found that children who are overweight are more likely to be in households experiencing food insecurity than children of normal weight. Williams et al. (2008) found that the availability of healthy, nutrient dense foods is limited in Appalachian home environments leading to the consumption of unhealthy junk foods.

\section{Causes of Food Insecurity and Hunger}

Food insecurity is often a result of poverty, residential instability and low food access. States in which people frequently move often have higher rates of food insecurity 
(Bartfield et al. 2006). People move to find employment or reduced housing costs. Long distance moves could weaken social ties to family and friends, which are used to protect against food insecurity. Townsend et al. (2001) found that poverty is the most significant predictor of food insecurity. The central Appalachian region, which includes all of West Virginia, has suffered a poverty level that is nearly twice the national average (Lichter and Campbell 2005). In 2008, West Virginia had a poverty level of $17.0 \%$ and an unemployment rate of 5.7\% (U.S. Bureau of Census, 2008 American Community Survey). Rural counties located in the Appalachian region are at an increased risk of poverty due to geographic isolation, an aging population, and inadequate economic infrastructures. In contrast to Townsend, Bartfield et al. (2006) found no evident link between poverty rate and household food insecurity. Rather, they found that needsadjusted income at the household level was the strongest predictor (Bartfield et al. 2006). Adjusted income is the annual income reduced by deductions for dependants, elderly households, medical expenses, disability expenses and child care.

The Appalachian Regional Commission uses an index-based economic classification system to identify economic levels of Appalachian counties. Of the 420 counties in the Appalachian region, 161 are designated as distressed or at-risk (Appalachian Regional Commission 2010). Distressed counties rank in the worst 10\% of the nation's counties according to socioeconomic indicators such as poverty levels and unemployment rate. Kentucky and West Virginia possess the most distressed counties in the region. Counties in West Virginia represent twenty at-risk and eleven distressed. A full map of the Appalachian region is included in Appendix 1. 
Food access represents a considerable challenge for rural, high poverty communities. Environmental factors such as long traveling distances to adequate food sources and difficult weather conditions limit physical access for people with low incomes, those without vehicles, children and the elderly. Since the 1960s, there has been a rapid growth of large chain-owned supermarkets or supercenters in out-of-town locations, usually on main arterial roads (White 2007). Many supercenters combine groceries, home items, electronics and much more to create a one-stop shopping environment. This consolidation has led to fewer but larger grocery stores (Morton et al. 2005). While the supercenters are often located within these limited geographic areas, individuals outside of these retail centers become isolated from convenient access to low cost, quality food (Blanchard and Lyson 2002).

Recent research has identified food deserts or counties with low accessibility to supermarkets and adequate food sources, as significant populations at risk of being food insecure. The concept of food deserts originated from a series of studies in the United Kingdom examining the characteristics of low-income, urban neighborhoods and growing spatial inequalities in food access (Guy and David 2004). Food deserts are caused by growth in more populated areas of superstores, and insufficient population base, and changes in food distribution channels (Morton and Blanchard 2007). Research on food deserts in the United States is relatively new, which has led to some inconsistencies in terminology.

Morton and Blanchard (2007) found that many food deserts are located in the Deep South and in the Appalachian region of Kentucky and West Virginia (2007). Early studies defined food deserts as counties in which all residents must travel ten or more 
miles to access large food retailers. Other counties with greater than $50 \%$ of the population but less than the total population lacking access are considered low access. A recent movement to define non-metropolitan food deserts identifies two classifications based on spatial indexes. A non-metropolitan county is classified as a food desert if the proportion of the county's population in a food desert is greater than the median proportion for the region of the U.S. in which the county is located (Blanchard and Lyson 2006). Severe food deserts are defined as counties in which the total county population resides in a food desert.

Food deserts are more likely to be structurally and economically disadvantaged. Many of these areas have been abandoned by retailing, as larger stores have consolidated into more metropolitan areas (Kaufman 2000). The decrease in city and county wide infrastructure leads to insufficient tax bases, unemployment and eventually abandonment of the commercial areas. Studies have shown that individuals in areas with low access to large food retailers often pay a higher premium for groceries and/or incur a greater travel cost (Kaufman 2000).

Excessive food costs are a significant result of low food access and food deserts. Supermarkets can charge lower prices, partly due to their lower operating costs and larger item selection, including store label and generic items (Kantor 2001). Small grocers must absorb the cost of purchasing and transporting smaller quantities of food. Healthy foods such as fruits, vegetables, whole grain breads and dairy products are even more difficult for the rural poor to access. Research indicates that low-income people generally cannot afford healthier foods (Mooney 1986). Instead, they rely on purchasing smaller quantities of food, generally processed food (Morland et al. 2002). 
Food retail isolation has been linked to more problems than hunger and food insecurity. Residents of food deserts often rely on low-cost convenience foods that provide inadequate sources of nutrients. Obesity, heart disease, diabetes and other health problems have been associated with food access and food deserts. Schaft et al. (2009) found in Pennsylvania students that the locations of aggregate level food deserts are positively associated with increased rates of obesity. Research on food deserts in the nonmetropolitan South found that residents of food desert counties were 23.4 times less likely to consume the recommended five or more servings of fruits and vegetables per day than those in non-food desert counties (Blanchard and Lyson 2006). Challenges of Alleviating Food Insecurity and Hunger

There are three major categories of food sources available: the normal food system (grocery stores and food service operation), government assistance (WIC, school lunch, nutrition programs for the elderly), and alternative food sources (private food assistance, gifts from family and friends) (Campbell 1991). While there has been considerable research performed on the normal food system and government assistance, there has been a lack of research focusing on private assistance, such as emergency food providers. One government and one private study have collected quality research on private organizations providing services.

Hunger in America, a national research study performed every three years since 1993, collects data on the characteristics of the clients served and the agencies that provide these services. Hunger in America is co-sponsored by Feeding America (FA), a national network of food banks in the United States, including two in West Virginia. Food banks serve as centralized warehouses for the collection of emergency food, which 
is distributed to smaller agencies (e.g. food pantries) that provide food to consumers (Duffy et al. 2006). Agencies operate within local communities as emergency food providers. These agencies operate feeding programs that provide direct services to those in need. In most cases, these programs are operated by volunteers and funded by donations from the community, which puts them in as much risk as those that seek their services.

Hunger in America 2010 collected data from emergency food providers in the service areas of 185 FA network food banks in the United States. Emergency food providers are programs whose main focus is to provide hunger relief. This includes food pantries, soup kitchens and shelters. Food pantries assist low-income households by providing them with packages of food to take home, which usually require additional preparation (Ohls and Saleem-Ismail 2002). Soup kitchens provide cooked meals to needy, usually a single meal per day, at local churches or community centers.

Occasionally, kitchens offer meals that can be taken home. Shelters also prepare food that can be eaten on-site and offer people short-term places to stay.

While these programs provide invaluable services to the community, they often struggle to survive. More than two thirds of these programs face critical problems due to funding, food resources, staffing and volunteers. According to Hunger in America, 27\% of pantries and $43 \%$ of shelters had turned clients away in the past year (Cohen et al. 2010). A similar study by the USDA found that a third of all food pantries reported turning clients away who requested food (Ohls et al. 2002). Although the majority of kitchens and pantries do not turn people away, about $40 \%$ limit households to receiving food once per month or less, and one-third of kitchens serve meals only one day per week 
(Ohls and Saleem-Ismail 2002). While many of these programs cite a lack of food resources, others turned clients away because they abused the program or showed signs of alcohol or drug abuse.

Food banks are the leading suppliers of feeding programs, providing $76 \%$ of food to all food pantries (Cohen et al. 2010). Other sources include The Emergency Food Assistance Program (TEFAP), the Commodity Supplemental Food Program (CSFP), church donations, food drives and merchant donations. Over half of all food pantries receive food through the TEFAP program at no cost, which is distributed by the USDA from surplus commodities.

Many food pantries and soup kitchens rely solely on volunteer staff while shelters have an average paid staff of nine (Cohen et al. 2010). Paid staff members tend to be able to provide more thorough services than volunteers that only work once or twice a month. Edlefsen and Olson (2002) found that while more involved administrators had a greater understanding of the client's situations, volunteers often had no more understanding than the public.

While emergency feeding programs provide short term relief to people in need, they may not confront the root causes of food insecurity. Duffy et al. (2006) finds that the majority of food programs fail to address social and psychological characteristics of food security definitions. Other critics complain that food banks and feeding programs have outgrown their original purpose. Poppendieck (1998) believes that instead of helping people become economically independent, feeding programs likely have the opposite effect. Daponte et al. (1998) found that low-income food pantry users in Allegheny County, PA often became chronic users, with a median length of two years. 
The purpose of this study is to assess the overall stability of emergency food providers in low access counties of West Virginia in comparison to other programs in the United States. It also examines the differences in challenges faced by low access and severely low access counties in West Virginia, if any. The following research questions are posed:

1. How do emergency food providers in West Virginia compare to those elsewhere in the country in relation to overall stability and challenges faced?

2. Do provider challenges differ between the low access and severely low access counties? If so, how?

3. What are the implications for addressing hunger in West Virginia? 


\section{Methods of Data Collection and Analysis}

This chapter explains the research methods used to conduct this study. The following pages include the study design, site selection, methods for data collection, and techniques of data analysis.

Study Design and Site Selection

This study collects data from all emergency food providers in the Feeding America network from Clay and Webster counties. These two counties were purposively selected because they are classified as low food access, economically distressed counties in West Virginia. Programs in these two counties were also easily accessible by the researcher for in-person interviews and data collection.

The Appalachian Regional Commission (ARC), a federal-state partnership that works for sustainable communities in the Appalachian region, has developed an index to classify counties based on their three year average of economic indicators- poverty rate, unemployment rate, and per capita market income. Each county is classified in one of five economic status designations ranging from attainment counties, at best, to distressed counties at worst. A distressed county is defined as ranking in the worst ten percent of the nation’s counties. As of the fiscal year 2010, West Virginia contains eleven distressed counties, including Clay and Webster counties. No counties in West Virginia have reached attainment status.

Clay County

Clay County is geographically located near the center of West Virginia, with four state routes and one interstate traveling through the county. According to the U.S. Census (2000), the population includes 4,020 households housing 10,330 residents. Of the 
population, only $63.7 \%$ have graduated high school or a higher level of education (U.S. Census 2000). Major industries include construction, manufacturing, health and social services. The mining industry continued to rise into the early 2000's, but production has dropped due to the economic struggles.

According to the 2000 U.S. Census, Clay County ranks last in the state, at $55^{\text {th }}$, with a per capita income of $\$ 19,113$, an increase from $\$ 12,147$ in 1996 . The poverty rate is $27.5 \%$, more than double the national average of $13.2 \%$. As of June 2010, Clay County had an unemployment rate of 13.8\%, ranking the highest in West Virginia (Bureau of Labor Statistics 2010). Of the employed works in Clay County, 65.6\% travel outside of the county for work (Bureau of Business and Economic Research 2008). Many workers incorporate shopping with work travel in order to reduce food and living costs.

Although Clay County contains a major interstate in its boundaries, many of its residents are isolated from shopping centers or large discount grocers. The county seat of Clay contains the only grocery store, with limited selections. The nearest large supermarket is at least 45 miles away, and even further to reach a supercenter such as Walmart or Kroger.

Webster County

Webster County is located slightly east of the center of West Virginia, with three state routes and no interstate access. They have a population of 4,010 households and 9,719 residents according to the 2000 U.S. Census. Of the population, 58.2\% have a high school diploma, with $8.7 \%$ holding a college degree. Major industries are agriculture, mining, manufacturing, retail, education, health and social services. 
Webster County ranks $50^{\text {th }}$ in the state with a per capita income of $\$ 20,298$ (U.S. Census 2000). While the income levels are higher, the poverty rate is $31.8 \%$ and the unemployment rate is 11.7\% (Bureau of Labor Statistics 2010). Of the employed workers in Webster County, 77.0\% travel outside of the county for work (Bureau of Business and Economic Research 2008). Coal mining jobs represent an important part of the economic sector, but have declined since its peak in 1996. The manufacturing industry has remained steady with health services peaking in 2000.

At the time of this research, Webster had one small grocery store near the county seat. Another small store had recently closed, with plans of reopening under new management in the future. Travel to a supermarket or supercenter includes trips of at least one hour or 35-45 miles.

Morton and Blanchard (2007) found that both counties (Clay and Webster) fall into the category of low food access, or 50 percent of the total population lacks convenient access to a supermarket or supercenter. Further research by Blanchard and Lyson (2006) has recognized Webster County as a severe food desert. For the purpose of this study, Clay County will be considered low access from the results of Morton and Blanchard (2007).

\section{Data Collection}

This research uses self-administered questionnaires that were sent to program administrators at each emergency food provider in Clay and Webster counties. The instrument used is similar to the questionnaire used in Hunger in America designed by Mathematica Policy Research. The purpose of this is to draw accurate comparisons of 
food providers on a national level. A list of programs was provided by the regional food bank that distributes food to the two counties.

Program administrators were contacted by telephone and asked to participate in the study by filling out the questionnaire, which was followed up by a short in-person interview. The questionnaire consisted of twenty-eight questions to collect descriptive data about the providers and the problems that may threaten their programs. The questions asked about what type of programs are being operated, the longevity of each program and the services provided. See Appendix 2 for the full questionnaire. The main focus of the questionnaire was to collect data on the stability and threats against the continued operation of the programs. The following six measures were used to collect data and assess stability of the emergency food providers:

- Is the continued operation of the selected programs threatened by one or more serious problems?

- During the past year, how often did each of the selected programs have to reduce meal portions or reduce quantity of food in food packages because of a lack of food?

- During the past year, did the selected programs turn away any clients for any reason?

- For which of the following reasons did each selected program turn clients away?

- During the past year, approximately how many clients did each selected program turn way?

- In your opinion, during a typical week, how much more food, if any, does each of the selected programs need in order to adequately meet their demand for food?

Open-ended interviews were conducted with program administrators of eleven of the fourteen emergency food providers in Clay and Webster counties. The purpose of the interviews was to clarify and expand on the responses to the questionnaire, and to 
generate higher level descriptions of the problems that threaten these programs.

Administrators were asked to provide examples and experiences of their problems, the solutions they are using to overcome these problems, and the outlook on the future of hunger in West Virginia. Informed consent was received from all interviewees prior to each interview. The understanding of the actions these providers are taking to offset their problems will help explain the future of hunger in West Virginia.

\section{Techniques for Analyzing Data}

The raw data collected from each questionnaire was entered into a database and tabulated using SPSS software. Frequency tables showing data statistics were created for county level data to create a general profile of each county. Data from the indicator questions were clustered by county and by program type. The data from these questions were then compared to national data from the Hunger in America 2010 study.

Tables were created based on the weighted total number of usable responses from the questionnaire. After programs from each county were compared with the national data, tabulations between the two counties were examined to compare and contrast the low food access county (Clay) and the severely low food access county (Webster).

All interviews were tape recorded with permission from the interviewee and transcribed by the researcher. The data analysis of the qualitative data began through the process of open coding each interview. Each interview was examined closely for sociological constructs and information related to the stability of the programs. The researcher also examined the data for in vivo codes during the coding process, which are terms taken from or directly derived from the language of the field. Open coding was followed by axial coding, which intensely examined the concepts and categories from the 
first phase of open coding. The core categories found during this process were focused on throughout the process of analysis and further data collection. Open and selective coding began immediately after the first interview.

Member checks were used during the interviews to provide confirmation that the responses provided were correctly understood. Constructs and excerpts from the interviews are used in the discussion and results section of this paper to present stronger evidence of findings from the questionnaires. 


\section{Results}

\section{Profiles of Agencies and Feeding Programs}

This chapter begins to present the results of the survey administered to program directors of agencies in Clay and Webster counties affiliated with the Feeding America network. The results of this survey represent agencies that receive supplies from the same regional food bank. All agencies operate feeding programs that distribute food to needy clients in their local communities. The first section below presents information on the types of programs represented by participating agencies. Next, we will examine characteristics of emergency feeding programs operated by these agencies, such as years of program operation, additional services provided, and the types of organizations that operate these programs.

\subsection{PARTICIPATING AGENCIES AND PROGRAMS}

The agency survey was sent to thirteen selected agencies affiliated with the Feeding America network. Each agency was asked to complete the survey with detailed information about one of each type of emergency food program that it operates (pantry, soup kitchen, and shelter). Agencies operating non-emergency food programs only were asked to complete the survey, however, the results were not included in this study.

Of the agencies that were asked to participate in the survey, all thirteen completed and returned the survey. Of those, all thirteen operate one or more emergency feeding programs, with two agencies also operating other non-emergency feeding programs. Table 1.1.1 shows the breakdown of the participating agencies by the type of program they operate. 
Table 1.1.1

PROGRAMS REPORTED ON BY PARTICIPATING AGENCIES

BY PROGRAM TYPE (Clay and Webster Counties)

\begin{tabular}{cccc|c|c}
\hline $\begin{array}{c}\text { Program } \\
\text { Type }\end{array}$ & $\begin{array}{c}\text { Clay } \\
\text { County }\end{array}$ & $\begin{array}{c}\text { Webster } \\
\text { County }\end{array}$ & $\begin{array}{c}\text { Total } \\
\text { (Both } \\
\text { Counties) }\end{array}$ & $\begin{array}{c}\text { Unweighted Total } \\
\text { Percentage }\end{array}$ & $\begin{array}{c}\text { Unweighted Total } \\
\text { Percentage Excluding } \\
\text { “Other” Type }\end{array}$ \\
Pantry & 6 & 3 & 9 & $56 \%$ & $64 \%$ \\
Kitchen & 3 & 2 & 5 & $31 \%$ & $36 \%$ \\
Shelter & 0 & 0 & 0 & $0 \%$ & $0 \%$ \\
$\begin{array}{c}\text { Other } \\
\text { Programs }\end{array}$ & 1 & 1 & 2 & $13 \%$ & n.a. \\
Total & 10 & 6 & 16 & $100 \%$ & $100 \%$ \\
\hline
\end{tabular}

Other programs include non-emergency food programs. These programs have a primary focus other than emergency food distribution. These programs may include daycare programs, after school programs, and senior health programs.

n.a. $=$ not available

Of the sixteen total programs reported on by participating agencies, $56 \%$ are pantries, 31\% are kitchens and none reported operating an emergency shelter. The remaining $13 \%$ are non-emergency food programs such as daycare programs, after school programs and senior health programs. When the non-emergency food programs are excluded 64\% are pantries and 36\% are kitchens.

Of the ten programs reporting from Clay County, $60 \%$ are pantries, $30 \%$ are kitchens and $10 \%$ are other non-emergency feeding program. When non-emergency feeding programs are excluded the percentages are 67\% pantries and 33\% kitchens.

Of the six programs reporting from Webster County, 50\% are pantries, 33\% are kitchens, and 17\% are non-emergency feeding programs. When non-emergency feeding programs are excluded $60 \%$ are pantries and $40 \%$ are kitchens. 


\subsection{Type of Agency That Operates the Program}

Table 1.2.1 shows the different types of agencies that operate emergency feeding programs in Clay and Webster counties.

Table 1.2.1

TYPE OF AGENCY

\begin{tabular}{ccccc}
\hline Type of Agency & $\begin{array}{c}\text { Pantry } \\
\text { Programs }\end{array}$ & $\begin{array}{c}\text { Kitchen } \\
\text { Programs }\end{array}$ & $\begin{array}{c}\text { Clay County } \\
\text { (All) }\end{array}$ & $\begin{array}{c}\text { Webster } \\
\text { County } \\
\text { (All) }\end{array}$ \\
$\begin{array}{c}\text { Faith Based or } \\
\text { Religious Non-profit }\end{array}$ & $67 \%$ & $20 \%$ & $56 \%$ & $60 \%$ \\
Other Private Non-profit & $11 \%$ & $40 \%$ & $22 \%$ & $20 \%$ \\
Governmental & $0 \%$ & $40 \%$ & $0 \%$ & $20 \%$ \\
Community Action Program & $22 \%$ & $0 \%$ & $22 \%$ & $0 \%$ \\
Other & $0 \%$ & $0 \%$ & $0 \%$ & $0 \%$ \\
SAMPLE SIZE (N) & 9 & 5 & 9 & 5 \\
\hline
\end{tabular}

SOURCE: This table was constructed based on usable responses to Question 18 of the agency survey.

NOTES: The percentages presented in this table are based only on usable responses, excluding missing, don’t know, and refusal responses.

Table 1.2.1 shows that $67 \%$ of pantries and $20 \%$ of kitchens are operated by faithbased organizations. Of all programs, 56\% in Clay and 60\% of programs in Webster are run by faith-based organizations. Other findings include:

- $40 \%$ of kitchens and $11 \%$ of pantries are operated by private non-profits other than faith-based

- $22 \%$ of pantries are operated by Community Action Programs

- $40 \%$ of kitchens are run by governmental organizations. $20 \%$ of programs in Webster County are operated by government based programs 


\subsection{Length of Program Operation}

Respondents identified the year that their emergency feeding program opened.

Table 1.3.1 shows the length of program operation for all counties (Clay and Webster).

Also shown are the average and median length of program operations.

Table 1.3.1

LENGTH OF PROGRAM OPERATION

\begin{tabular}{|c|c|c|c|}
\hline $\begin{array}{c}\text { How long the program has been } \\
\text { operating? }\end{array}$ & Pantry Programs & $\begin{array}{l}\text { Kitchen } \\
\text { Programs }\end{array}$ & $\begin{array}{c}\text { Programs with Pantry } \\
\text { or Kitchen }\end{array}$ \\
\hline 2 years or less & $22 \%$ & $20 \%$ & $21 \%$ \\
\hline 3-4 years & $11 \%$ & $20 \%$ & $14 \%$ \\
\hline 5-6 years & $11 \%$ & $0 \%$ & $7 \%$ \\
\hline 7-10 years & $22 \%$ & $0 \%$ & $14 \%$ \\
\hline $11-20$ years & $22 \%$ & $20 \%$ & $21 \%$ \\
\hline 21-30 years & $11 \%$ & $20 \%$ & $14 \%$ \\
\hline More than 30 years & $0 \%$ & $20 \%$ & $7 \%$ \\
\hline \multirow[t]{2}{*}{ SAMPLE SIZE (N) } & 9 & 5 & 14 \\
\hline & Pantry Programs & $\begin{array}{l}\text { Kitchen } \\
\text { Programs }\end{array}$ & $\begin{array}{l}\text { Programs with Pantry } \\
\text { or Kitchen }\end{array}$ \\
\hline $\begin{array}{c}\text { Average Length of Operation(in } \\
\text { years) }\end{array}$ & 10 & 17 & 12 \\
\hline $\begin{array}{l}\text { Median Length of } \\
\text { Operation (in years) }\end{array}$ & 7 & 14 & 9 \\
\hline SAMPLE SIZE (N) & 9 & 5 & 14 \\
\hline
\end{tabular}

Source: This table was constructed based on responses to Question 3b. of the agency survey.

The average length of operation among panty programs is 10 years. The average program length for kitchens is 17 years. For all programs together the average life is 12 years. 
Other findings include:

- $22 \%$ of pantries and $20 \%$ of kitchens have been operating for less than 2 years

- When combined, $44.4 \%$ of pantries have been operating from 7 to 20 years, but only $20 \%$ of kitchens

- $11.1 \%$ of pantries and $20 \%$ of kitchens have been operating from 21 to 30 years

- Only $20 \%$ of kitchens and no pantries have operated more than 30 years When combined together, pantries and kitchens have an average program life of 12 years. The median life of both programs together is 9 years.

\subsection{Other Services in Addition to Food Distribution}

Agencies were asked to choose other services and programs that their programs provided from a list in the survey. These services vary from other food-related support to housing aid and financial support. Table 1.4.1 shows results from data. Total counts are distributed by pantry or kitchen and by county. Data is shown by county to represent what types of services may be available in each county. 
Table 1.4.1

OTHER SERVICES OR PROGRAMS PROVIDED
IN ADDITION TO FOOD DISTRIBUTION, BY PROGRAM TYPE

$\begin{array}{cccc}\begin{array}{c}\text { Pantry } \\ \text { Programs } \\ \text { (Total) }\end{array} & \begin{array}{c}\text { Kitchen } \\ \text { Programs } \\ \text { (Total) }\end{array} & \begin{array}{c}\text { Clay County } \\ \text { (All) }\end{array} & \begin{array}{c}\text { Webster } \\ \text { County (All) }\end{array}\end{array}$

Food Related Support

\begin{abstract}
Nutrition Counseling
Eligibility Counseling for WIC

Eligibility Counseling for Food Stamps
\end{abstract}

\title{
Other Client Training
}

Employment Training
Retraining Physically
Disabled
Retraining Mentally
Ill/Challenged
Legal Services/Tax
Preparation
Utility Bill Assistance
Short Term Financial
Assistance
Budget/Credit Counseling
or Consumer Protection

\section{Other Client Direct Services}

\begin{tabular}{|c|c|c|c|c|}
\hline $\begin{array}{l}\text { Health services and } \\
\text { health clinics }\end{array}$ & 1 & 0 & 1 & 0 \\
\hline Transportation & 1 & 2 & 2 & 1 \\
\hline Clothing/Furniture & 4 & 0 & 3 & 1 \\
\hline $\begin{array}{l}\text { Subsidized Housing } \\
\text { Assistance }\end{array}$ & 1 & 0 & 1 & 0 \\
\hline Housing Rehabilitation & 0 & 0 & 0 & 0 \\
\hline $\begin{array}{l}\text { Supported Employment } \\
\text { (Job Training) }\end{array}$ & 1 & 1 & 2 & 0 \\
\hline $\begin{array}{l}\text { red at least One other } \\
\text { e than food distribution }\end{array}$ & 7 & 4 & 7 & 4 \\
\hline $\begin{array}{l}\text { Two or more other } \\
\text { es than food distribution }\end{array}$ & 6 & 1 & 5 & 2 \\
\hline
\end{tabular}

Offered at least One other service than food distribution

Offered Two or more other services than food distribution

Source: This table was constructed based on responses to Question 4 of the agency survey. 
Nutrition counseling is offered by two pantries and two kitchens. Three programs in Webster County offer nutrition counseling, while only one in Clay offers this service. Of all pantries, three offer counseling for WIC and Food Stamp eligibility. Other findings include:

- Three kitchens offer employment training

- Four pantries offer utility bill assistance, while no kitchens offer this

- Four pantries offer clothing or furniture assistance. Three programs in Clay and one in Webster offer this service

- Seven pantries and four kitchens offer at least one other service than food distribution

- Six pantries and one kitchen offer two or more services other than food distribution 


\section{Service Levels of Feeding Programs}

This chapter examines the different levels of service that feeding programs in Clay and Webster counties provide. Programs vary in size based on staffing, food sources, and organizational structure. The analysis below will examine people or households served in the past year, meal or boxes given out, and whether feeding programs have seen an increase of more clients.

\subsection{Number of Different People or Households Served in the Past Year}

Agencies were asked how many different people or different households were served by their feeding program in the past year. Table 2.1.1 presents the results.

Table 2.1.1

AMOUNT OF DIFFERENT PEOPLE OR DIFFERENT HOUSEHOLDS SERVED BY THE FOOD PROGRAM BETWEEN JANUARY 1, 2009 AND DECEMBER 31, 2009

\begin{tabular}{ccccc}
\hline $\begin{array}{c}\text { Amount of Different People or } \\
\text { Households served in 2009 }\end{array}$ & $\begin{array}{c}\text { Pantry } \\
\text { Programs }\end{array}$ & $\begin{array}{c}\text { Kitchen } \\
\text { Programs }\end{array}$ & Clay County & $\begin{array}{c}\text { Webster } \\
\text { County }\end{array}$ \\
$1-9$ & $0 \%$ & $0 \%$ & $0 \%$ & $0 \%$ \\
$10-29$ & $0 \%$ & $20 \%$ & $12.5 \%$ & $0 \%$ \\
$30-49$ & $12 \%$ & $0 \%$ & $12.5 \%$ & $0 \%$ \\
$50-99$ & $25 \%$ & $20 \%$ & $25 \%$ & $20 \%$ \\
$100-149$ & $25 \%$ & $20 \%$ & $25 \%$ & $20 \%$ \\
$150-199$ & $0 \%$ & $20 \%$ & $0 \%$ & $20 \%$ \\
$200-249$ & $0 \%$ & $0 \%$ & $0 \%$ & $0 \%$ \\
250 or more & $38 \%$ & $20 \%$ & $25 \%$ & $40 \%$ \\
TOTAL & $100 \%$ & $100 \%$ & $100 \%$ & $100 \%$ \\
SAMPLE SIZE (N) & 8 & 5 & 8 & 5 \\
\hline
\end{tabular}

SOURCE: This table was constructed based on usable responses to Question 5 of the agency survey.

NOTES: The percentages presented in this table are based only on usable responses, excluding missing, don't know, and refusal responses. All usable responses were weighted to represent all emergency food programs. The sample sizes $(\mathrm{N})$ also include missing data. Missing, don't know, and refusal responses combined are $11 \%$ for pantry programs and $0 \%$ for kitchen programs. 
Of the participating agencies, 38\% of pantries and 20\% of kitchens served more than 250 different people or households in 2009. 40\% of programs in Webster County served more than 250 different people or households. The following findings include:

- $25 \%$ of pantries served in between 50 to 99 different households. Another $25 \%$ served between 100 and 149 households. So overall, 50\% of pantries served between 50 and 149 households in the past year.

- Programs in Clay County were more likely to serve smaller populations. $12.5 \%$ served between 10 and 29 people or households and another $12.5 \%$ served between 30 and 49 .

- All programs in Webster County served populations greater than 50. Only 20\% served 50 to 99 people or households, while the remaining $80 \%$ served 100 or more. 


\subsection{Amount of Meals or Bags/Boxes Distributed in a Typical Week}

Agencies were asked how much food they gave out during a typical week. Many of the programs only operated monthly or bi-monthly, in which they gave estimated answers to represent a weekly basis. Table 2.2.1 shows the results.

Table 2.2.1

\section{AMOUNT OF MEALS OR BAGS/BOXES DISTRIBUTED DURING A TYPICAL WEEK}

\begin{tabular}{ccccc}
\hline $\begin{array}{c}\text { Amount of Meals or } \\
\text { Bags/Boxes Distributed in a } \\
\text { Typical Week }\end{array}$ & $\begin{array}{c}\text { Pantry } \\
\text { Programs }\end{array}$ & $\begin{array}{c}\text { Kitchen } \\
\text { Programs }\end{array}$ & $\begin{array}{c}\text { Clay County } \\
\text { (All) }\end{array}$ & $\begin{array}{c}\text { Webster } \\
\text { County (All) }\end{array}$ \\
$1-9$ & $0 \%$ & $0 \%$ & $0 \%$ & $0 \%$ \\
$10-29$ & $17 \%$ & $0 \%$ & $14 \%$ & $0 \%$ \\
$30-49$ & $0 \%$ & $0 \%$ & $0.0 \%$ & $0 \%$ \\
$50-99$ & $33 \%$ & $0 \%$ & $29 \%$ & $0 \%$ \\
$100-149$ & $33 \%$ & $50 \%$ & $29 \%$ & $67 \%$ \\
$150-199$ & $0 \%$ & $0 \%$ & $0 \%$ & $0 \%$ \\
$200-249$ & $0 \%$ & $25 \%$ & $14 \%$ & $0 \%$ \\
250 or more & $17 \%$ & $25 \%$ & $14 \%$ & $33 \%$ \\
SAMPLE SIZE (N) & 6 & 4 & 7 & 3 \\
\hline
\end{tabular}

SOURCE: This table was constructed based on usable responses to Question 6 of the agency survey.

NOTES: The percentages presented in this table are based only on usable responses, excluding missing, don't know, and refusal responses. Missing, don't know, and refusal responses combined are 33\% for pantry programs and $20 \%$ for kitchen programs.

$33 \%$ of pantries distribute between 50 and 99 bags/boxes of food per week. 50\%

of kitchens serve between 100 and 149 meals during a typical week. Other results follow:

- $33 \%$ of pantries distribute between 100 and 149 bags/boxes per week.

- $17 \%$ of pantries and $25 \%$ of kitchens distribute 250 or more boxes of food or meals in a typical week.

- Only 29\% of programs in Clay County distribute between 100 and 149 meals or boxes compared to $67 \%$ of programs in Webster County. 


\subsection{Agencies Estimates of Change in Number of Clients}

Agencies were asked in the survey whether they serve more or fewer clients than they did in 2007. Table 2.3.1 presents the findings.

Table 2.3.1

AGENCY ESTIMATES OF CHANGES IN NUMBER OF CLIENTS FROM 2007-2010

\begin{tabular}{ccccc}
\hline $\begin{array}{c}\text { Agency Estimates of Changes } \\
\text { in Number of Clients from } \\
\text { 2007-2010 }\end{array}$ & $\begin{array}{c}\text { Pantry } \\
\text { Programs } \\
\text { (total) }\end{array}$ & $\begin{array}{c}\text { Kitchen } \\
\text { Programs } \\
\text { (total) }\end{array}$ & $\begin{array}{c}\text { Clay County } \\
\text { (All) }\end{array}$ & $\begin{array}{c}\text { Webster } \\
\text { County (All) }\end{array}$ \\
Fore clients & $89 \%$ & $80 \%$ & $78 \%$ & $100 \%$ \\
Fewer Clients & $0 \%$ & $0 \%$ & $0 \%$ & $0 \%$ \\
$\quad \begin{array}{c}\text { About the Same } \\
\text { Number of Clients }\end{array}$ & $11 \%$ & $0 \%$ & $11 \%$ & $0 \%$ \\
Program Did Not Exist & $0 \%$ & $20 \%$ & $11 \%$ & $0 \%$ \\
$\quad$ in 2007 & $100 \%$ & $100 \%$ & $100 \%$ & $100 \%$ \\
TOTAL & 9 & 5 & 9 & 5 \\
\hline SAMPLE SIZE (N) & & & & \\
\hline
\end{tabular}

SOURCE: This table was constructed based on usable responses to Question 7 of the Agency Survey.

The results show that $89 \%$ of pantries and $80 \%$ of kitchens indicate that they serve more clients now than they did in 2007.

- $11 \%$ of pantries felt that they were serving the same amount of clients.

- $78 \%$ of programs in Clay County indicated that they serve more clients now than in 2007.

- All (100\%) of programs in Webster County indicated that they serve more clients now than in 2007.

- No programs felt that they serve fewer clients. 


\section{Resources of Feeding Programs}

Many feeding programs operate from donated goods and volunteer time.

Therefore, it is important to understand where these programs receive their food and what sources of help programs have to operate. I began by examining the sources of food for emergency feeding programs in Clay and Webster counties and then I looked at the use of paid and unpaid staff to operate the programs.

\subsubsection{Sources of Food Distributed by Programs}

Agencies were asked what percent of the food distributed through their feeding program came from their regional food bank. TEFAP commodities are distributed through the local food bank. So agencies were asked if they distributed government or USDA commodities received from the food bank. Agencies were also asked if they received food from other sources such as food drives and local merchants.

Table 3.1.1

\section{SOURCES OF FOOD DISTRIBUTED BY PROGRAM}

\begin{tabular}{ccccc}
\hline Sources of Food & $\begin{array}{c}\text { Pantry } \\
\text { Programs }\end{array}$ & Kitchen Programs & $\begin{array}{c}\text { Clay } \\
\text { County } \\
\text { (All) }\end{array}$ & $\begin{array}{c}\text { Webster } \\
\text { County (All) }\end{array}$ \\
$\begin{array}{c}\text { Average Percent of Food } \\
\text { Received from Food Bank }\end{array}$ & $78 \%$ & $13 \%$ & $64 \%$ & $39 \%$ \\
Programs receiving from: & $100 \%$ & $20 \%$ & $78 \%$ & $60 \%$ \\
TEFAP & $67 \%$ & $20 \%$ & $56 \%$ & $40 \%$ \\
$\begin{array}{c}\text { Church or Religious } \\
\text { Congregations }\end{array}$ & $22 \%$ & $20 \%$ & $33 \%$ & $0 \%$ \\
$\begin{array}{c}\text { Local Merchant or Farmer } \\
\text { Donations }\end{array}$ & $56 \%$ & $20 \%$ & $44 \%$ & $40 \%$ \\
$\quad \begin{array}{c}\text { Local Food Drives } \\
\text { Food Purchased By } \\
\text { Agency }\end{array}$ & $67 \%$ & $80 \%$ & $67 \%$ & $80 \%$ \\
SAMPLE SIZE (N) & 9 & 5 & 9 & 5 \\
\hline
\end{tabular}

SOURCE: This table was constructed based on usable responses to Questions 8,8a, and 8b of the agency survey. 
NotEs: The percentages presented in this table are based only on usable responses, excluding missing, don't know, and refusal responses.

Pantries receive $78 \%$ of the food they distribute from their local food bank.

Kitchens only receive $13 \%$ of their food from the food bank. $100 \%$ of pantries distribute TEFAP commodities that they receive from the food bank, while only $20 \%$ of kitchens.

Other sources of food include:

- $67 \%$ of pantries receive food from churches or religious congregations.

- $56 \%$ of pantries receive food from local food drives, but only $20 \%$ of kitchens do the same.

- $80 \%$ of kitchens purchase food for their feeding program compared to $67 \%$ of pantries.

Programs in Clay County receive $64 \%$ of their food from the food bank, compared to 39\% in Webster County. 33\% of programs in Clay County receive donations from local merchants or farmers compared to $0 \%$ in Webster County. $56 \%$ of programs in Clay County receive donations from local churches or religious congregations.

\subsubsection{Paid Staff and Volunteer Resources}

Agencies were asked how many paid staff and volunteers they had and how many volunteer hours they had received in the past week. Table 3.2.1 shows the results. 
Table 3.2.1

\section{PAID STAFF AND VOLUNTEERS}

\begin{tabular}{|c|c|c|c|c|}
\hline Staff and Volunteer Resources & $\begin{array}{l}\text { Pantry } \\
\text { Programs }\end{array}$ & $\begin{array}{l}\text { Kitchen } \\
\text { Programs }\end{array}$ & $\begin{array}{c}\text { Clay } \\
\text { County } \\
\text { (All) }\end{array}$ & $\begin{array}{c}\text { Webster } \\
\text { County } \\
\text { (All) }\end{array}$ \\
\hline \multicolumn{5}{|l|}{ Number of Paid Staff } \\
\hline None & $78 \%$ & $20 \%$ & $67 \%$ & $40 \%$ \\
\hline $1-5$ & $22 \%$ & $60 \%$ & $22 \%$ & $60 \%$ \\
\hline $5-10$ & $0 \%$ & $0 \%$ & $0 \%$ & $0 \%$ \\
\hline More than 10 & $0 \%$ & $20 \%$ & $11 \%$ & $0 \%$ \\
\hline SAMPLE SIZE (N) & 9 & 5 & 9 & 5 \\
\hline Average Number of Paid Staff & 1 & 5 & 3 & 1 \\
\hline Median Number of Paid Staff & 0 & 4 & 0 & 2 \\
\hline \multicolumn{5}{|l|}{ Number of Volunteers Per Week } \\
\hline None & $0 \%$ & $60 \%$ & $11 \%$ & $40 \%$ \\
\hline $1-5$ & $44 \%$ & $20 \%$ & $33 \%$ & $40 \%$ \\
\hline $5-10$ & $22 \%$ & $20 \%$ & $22 \%$ & $20 \%$ \\
\hline $10-20$ & $22 \%$ & $0 \%$ & $22 \%$ & $0 \%$ \\
\hline 20 or more & $11 \%$ & $0 \%$ & $11 \%$ & $0 \%$ \\
\hline SAMPLE SIZE (N) & 9 & 5 & 9 & 5 \\
\hline $\begin{array}{l}\text { Average Number of } \\
\text { Volunteers Per Week }\end{array}$ & 7 & 3 & 7 & 3 \\
\hline $\begin{array}{l}\text { Median Number of } \\
\text { Volunteers Per Week }\end{array}$ & 6 & 1 & 6 & 2 \\
\hline SAMPLE SIZE (N) & 9 & 4 & 4 & 4 \\
\hline $\begin{array}{c}\text { Average Volunteer Hours } \\
\text { Per Week }\end{array}$ & 22 & 2 & 17 & 17 \\
\hline $\begin{array}{c}\text { Median Volunteer Hours } \\
\text { Per Week }\end{array}$ & 13 & 0 & 7 & 7 \\
\hline SAMPLE SIZE (N) & 9 & 3 & 8 & 4 \\
\hline
\end{tabular}

SOURCE: This table was constructed based on usable responses to Questions 15 and 16 of the agency survey.

NOTES: The percentages presented in this table are based only on usable responses, excluding missing and refusal responses. 
$78 \%$ of pantries had no paid staff to operate the feeding program. $60 \%$ of kitchens had a staff of 1 to 5 to operate the program.

- Pantries had an average number of paid staff of one, but a median number of zero paid staff.

- The average number of paid staff in all kitchens was five.

- $44 \%$ of pantries had 1 to 5 volunteers per week.

- $11 \%$ of pantries had 20 or more volunteers per week.

- $60 \%$ of kitchens had zero volunteers per week.

- The average number of volunteers for pantries was seven. The volunteers gave an average of 22 total hours per week to the pantry.

Programs in Clay County relied on volunteer staff more than Webster. 67\% of programs had no paid staff in Clay, compared to $40 \%$ in Webster County. Other findings include:

- $40 \%$ of programs in Webster had no volunteers during a typical week.

- $22 \%$ of programs in Clay had 10 to 20 volunteers per week. $11 \%$ had 20 or more volunteers.

- The average number of volunteers in Clay County is seven, compared to three in Webster County. 


\section{Stability of Feeding Programs}

Until this point, we have looked at the profiles of emergency feeding programs in Clay and Webster counties. The attention will now shift to the main focus of this research study: the stability and threats against the continued operation of emergency feeding programs. Below, I examine the stability of programs, the problems that they face, the severity of stretching resources in their community and whether they had to turn clients away during the year. I also look at what additional resources are needed and impact of the food bank for the feeding program. Results are compared to the Hunger in America 2010 results in order to compare and contrast the differences between the local and national picture. The results for pantries and kitchens are separated to take a closer look at each type of program.

\subsection{Problems that Threaten the Programs}

Agencies were asked whether they faced serious problems that may threaten the continued existence of the feeding program. Agencies were able to mark more than one problem or threat. Programs were also able to mark if they did not face any problems that might jeopardize the feeding program. The results for pantries are presented in Table 4.1.1 below. 
Table 4.1.1

PROBLEMS THAT THREATEN EXISTENCE

OF THE PANTRIES

\begin{tabular}{|c|c|c|c|c|}
\hline Nature of Problem & Clay County & $\begin{array}{l}\text { Webster } \\
\text { County }\end{array}$ & $\begin{array}{c}\text { Pantry Programs } \\
\text { (Both) }\end{array}$ & $\begin{array}{c}\text { National Ave. } \\
\text { Pantry Programs }\end{array}$ \\
\hline $\begin{array}{l}\text { Problems Related to } \\
\text { Funding }\end{array}$ & $83 \%$ & $33 \%$ & $67 \%$ & $48 \%$ \\
\hline $\begin{array}{l}\text { Problems Related to } \\
\text { Food Supplies }\end{array}$ & $67 \%$ & $100 \%$ & $78 \%$ & $42 \%$ \\
\hline $\begin{array}{l}\text { Problems Related to } \\
\text { Paid Staff or } \\
\text { Personnel }\end{array}$ & $0 \%$ & $0 \%$ & $0 \%$ & $7 \%$ \\
\hline $\begin{array}{c}\text { Problems Related to } \\
\text { Volunteers }\end{array}$ & $17 \%$ & $0 \%$ & $11 \%$ & $15 \%$ \\
\hline $\begin{array}{l}\text { Community } \\
\text { Resistance }\end{array}$ & $0 \%$ & $0 \%$ & $0 \%$ & $2 \%$ \\
\hline Other Problems & $0 \%$ & $0 \%$ & $0 \%$ & $4 \%$ \\
\hline $\begin{array}{l}\text { Programs Not } \\
\text { Facing Problems } \\
\text { that Continue to } \\
\text { Threaten Existence }\end{array}$ & $17 \%$ & $0 \%$ & $11 \%$ & $33 \%$ \\
\hline $\begin{array}{l}\text { Programs Facing } \\
\text { One or More } \\
\text { Problems that } \\
\text { Continue to } \\
\text { Threaten Existence }\end{array}$ & $83 \%$ & $100 \%$ & $89 \%$ & $67 \%$ \\
\hline SAMPLE SIZE (N) & 6 & 3 & 9 & 23,842 \\
\hline
\end{tabular}

SOURCE: This table was constructed based on usable responses to Question 17 of the agency survey.

NOTES: The percentages presented in this table are based only on usable responses, excluding missing, don’t know, and refusal responses.

* Data for national averages comes from the Hunger in America 2010 study performed by Feeding America.

Next, Table 4.1.2 shows the results of the problems facing emergency kitchens in Clay and Webster counties compared with the national results. 
Table 4.1.2

PROBLEMS THAT THREATEN EXISTENCE

OF THE KITCHENS

\begin{tabular}{|c|c|c|c|c|}
\hline Nature of Problem & Clay County & $\begin{array}{l}\text { Webster } \\
\text { County }\end{array}$ & $\begin{array}{l}\text { Kitchen Programs } \\
\text { (Both) }\end{array}$ & $\begin{array}{c}\text { National Ave. } \\
\text { Kitchen Programs* }\end{array}$ \\
\hline $\begin{array}{l}\text { Problems Related to } \\
\text { Funding }\end{array}$ & $67 \%$ & $100 \%$ & $80 \%$ & $56 \%$ \\
\hline $\begin{array}{l}\text { Problems Related to } \\
\text { Food Supplies }\end{array}$ & $33 \%$ & $0 \%$ & $20 \%$ & $32 \%$ \\
\hline $\begin{array}{l}\text { Problems Related to } \\
\text { Paid Staff or } \\
\text { Personnel }\end{array}$ & $0 \%$ & $0 \%$ & $0 \%$ & $16 \%$ \\
\hline $\begin{array}{c}\text { Problems Related to } \\
\text { Volunteers }\end{array}$ & $0 \%$ & $0 \%$ & $0 \%$ & $16 \%$ \\
\hline $\begin{array}{l}\text { Community } \\
\text { Resistance }\end{array}$ & $0 \%$ & $0 \%$ & $0 \%$ & $5 \%$ \\
\hline Other Problems & $0 \%$ & $0 \%$ & $0 \%$ & $3 \%$ \\
\hline $\begin{array}{l}\text { Programs Not } \\
\text { Facing Problems } \\
\text { that Continue to } \\
\text { Threaten Existence }\end{array}$ & $33 \%$ & $0 \%$ & $20 \%$ & $33 \%$ \\
\hline $\begin{array}{l}\text { Programs Facing } \\
\text { One or More } \\
\text { Problems that } \\
\text { Continue to } \\
\text { Threaten Existence }\end{array}$ & $67 \%$ & $100 \%$ & $80 \%$ & $67 \%$ \\
\hline SAMPLE SIZE (N) & 3 & 2 & 5 & 6,064 \\
\hline
\end{tabular}

SOURCE: This table was constructed based on usable responses to Question 17 of the agency survey.

NOTES: The percentages presented in this table are based only on usable responses, excluding missing, don't know, and refusal responses.

*Data for national averages comes from the Hunger in America 2010 study performed by Feeding America.

Below in Table 4.1.3 is the results for all programs in Clay and Webster counties that face problems that may threaten their continued existence. 
Table 4.1.3

PROBLEMS THAT THREATEN EXISTENCE OF ALL PROGRAMS IN CLAY AND WEBSTER

\begin{tabular}{|c|c|c|c|}
\hline Nature of Problem & Clay County & Webster County & All Programs (Clay and Webster) \\
\hline $\begin{array}{l}\text { Problems Related to } \\
\text { Funding }\end{array}$ & $78 \%$ & $60 \%$ & $71 \%$ \\
\hline $\begin{array}{l}\text { Problems Related to } \\
\text { Food Supplies }\end{array}$ & $56 \%$ & $60 \%$ & $57 \%$ \\
\hline $\begin{array}{l}\text { Problems Related to } \\
\text { Paid Staff or } \\
\text { Personnel }\end{array}$ & $0 \%$ & $0 \%$ & $0 \%$ \\
\hline $\begin{array}{c}\text { Problems Related to } \\
\text { Volunteers }\end{array}$ & $11 \%$ & $0 \%$ & $7 \%$ \\
\hline $\begin{array}{l}\text { Community } \\
\text { Resistance }\end{array}$ & $0 \%$ & $0 \%$ & $0 \%$ \\
\hline Other Problems & $0 \%$ & $0 \%$ & $0 \%$ \\
\hline $\begin{array}{l}\text { Programs Not } \\
\text { Facing Problems } \\
\text { that Continue to } \\
\text { Threaten Existence }\end{array}$ & $11 \%$ & $0 \%$ & $14 \%$ \\
\hline $\begin{array}{l}\text { Programs Facing } \\
\text { One or More } \\
\text { Problems that } \\
\text { Continue to } \\
\text { Threaten Existence }\end{array}$ & $89 \%$ & $100 \%$ & $86 \%$ \\
\hline SAMPLE SIZE (N) & 9 & 5 & 14 \\
\hline
\end{tabular}

SOURCE: This table was constructed based on usable responses to Question 17 of the agency survey.

NoTES: The percentages presented in this table are based only on usable responses, excluding missing, don't know, and refusal responses.

The results of the questionnaire reveal that problems with funding and supplies of food are the most severe threats to the existing feeding programs. $83 \%$ of pantries and $67 \%$ of kitchens in Clay County have concerns over funding. On the other hand, only $33 \%$ of pantries, but $100 \%$ of kitchens in Webster County have issues with funding. These results compare to a national average of $48 \%$ of pantries and $56 \%$ of kitchens. 
Many of the feeding programs rely on donations, small grants and government funding to offset operating costs and food purchasing. The data from Clay County reflect a 35\% difference in the amount of pantries that face problems with funding compared nationally.

When asked if they have problems that threaten their program, administrators expressed the following responses:

"Funding is a problem...because we are $100 \%$ grant funded."

"Number one is money. Lack of money and lack of manpower. And then, the lack of just being able to get food [for the program].”

"No...other than funding..."

"Because we're a non-profit, we work basically in the hole"

“There were times when we didn't have enough money in the bank to pay for what we were getting [to give out]."

"We try to get as much all through the county as we can, of course, there's lots of place we just can't do it...cause we don't have the money."

“We have to depend on donations and our people just don't have extra."

"If anything that we have now was cut, it would be bad...."

"For the food pantry, we have to use our money the best way we can."

Through the process of interviewing the administrators, it became clear that the majority of the programs relied heavily on single sources of funding (e.g. grants, government funding, and donations) and used other sources to supplement their program budget. Programs that rely solely on donations struggle to maintain funding, always working with the funding that they will have. The program that responded "we basically work in the hole” exemplified it best. These programs provide their services and products to the public under the assumption and hope that the funding will come in by the end of 
the month to cover the expenses. As one administrator responded, "we didn’t have enough money in the bank to pay for what we were getting”. Like the clients that they serve, the feeding programs in Clay and Webster operate month by month.

The programs that are government or grant funded also seem to operate on a year to year basis. A weak economy and government cuts have affected many feeding programs. One response was, "if anything we have now was cut, it would be bad.” These programs are often one cut away from be eliminated. A few programs are backed by larger national faith-based organizations which provide outside funding.

Nevertheless, the programs have learned to adapt and continue even in difficult times. Several administrators responded that even if they did run out of food, they would purchase food themselves to give to the clients. Unfortunately, this takes a financial and mental toll on the administrators, due to the fact that they are struggling as well. Some faith based programs pool their resources together to offer a better food distribution. Other programs have responded by offering additional services to the clients in order to receive government aid. One feeding program, for example, began offering in-home services such as cleaning and transportation, as well as meal deliveries.

In addition to funding, low supplies of food threaten the future of the programs. The questionnaire showed that in Clay County, 67\% of pantries and 33\% of kitchens feel that their ability to keep supplies of food threatens their program. In Webster County, $100 \%$ of the pantries feel threatened, while no kitchens are worried about their food supplies. In comparison with national data, Clay County pantries have a 25\% higher percentage of concern for food supplies, while Webster County pantries have a 58\% 
higher percentage. Kitchens are, on average, are statistically similar in Clay and much lower in Webster County.

The following are responses about food supplies:

"If somebody comes in, and they need something, if we have it...we usually don't...we give it to them."

“We just don't have it, we barely have enough to give out the little bit we give."

"And that would clean us totally out...really, we really can't handle more than that." "We have to cut off some food at times."

"We get a lot of comments that this pantry gives more than other pantries do."

"Usually by February or March we run out...it's really hard for me to supplement it [the feeding program]."

Pantries in both Clay and Webster counties struggle to maintain food supplies throughout the year. Of the pantries, $100 \%$ receive and distribute USDA commodities from the local food bank. Commodities are allocated cost-free to feeding programs as a method of increasing the foods given out per county.

Other supplies of food include donations from food drives, purchased foods, and other items received from the local food bank. Programs in Clay County receive 64\% of their food from the food bank, compared to 39\% in Webster County. Of the programs in Clay County, 67\% purchase additional food for their program. In Webster County, 80\% of programs do the same.

The majority of feeding programs distribute limited amounts of each type products, depending on client household size and income levels. In order to receive USDA commodities, a client must be below certain income guidelines, usually below 185 percent of the U.S. poverty levels. Clients that exceed those guidelines may receive items 
from the general inventory, when available. Feeding programs generally give out everything from the general inventory the monthly distribution date. One administrator stated, “[And] that would totally clean us out.”

In addition to funding and food, participating agencies reported that volunteers and lack of space or location were threats to their operation. Pantries in both counties rely on a small group of reliable citizens to operate the program. $78 \%$ of pantries in Clay and Webster have no paid staff, and rely completely on volunteers. The remaining $22 \%$ have a small paid staff, normally consisting of one or two individuals to manage financial accounts and bookkeeping. Of the pantries operated by volunteers, $44 \%$ have only $1-5$ volunteers per week. Only $17 \%$ of pantries in Clay County reported having problems keeping volunteers, which is close to the national average of $15 \%$.

In both counties, kitchens reported no problems with maintaining volunteers, mostly because they rely on paid staff to regularly prepare and deliver meals. Volunteers assume expendable responsibilities, such as cleaning up and sorting donations. A paid staff is almost necessary to keep up federal and state regulations associated with providing safe food.

From the interviews, I learned that a lack of adequate storage space or location to host pantries was a concern for several programs. The following quotes were taken from administrators on the subject:

"Space...we need more space for our program."

“Oh, we could do triple what we do now...we just don't have anyplace to store it.” "That's another thing that worries me is the location." 
Of the pantries, $67 \%$ reported they were part of a faith-based organization, while another $22 \%$ were part of a community action program. Space is usually donated to these programs from the local church or town government. Several of the programs admitted that the space they operate from was inadequate for the task at hand, and could be lost if the church or town decided to remove them.

Refrigerated and freezer space is a severe issue for many of the pantries. Many could not afford to purchase more than one or two freezers/refrigerators for frozen meats, produce, and dairy products. If the appliances went down, they were usually not replaced unless someone donated one. Kitchens did not have problems with storage or space in either county. 


\subsection{Frequency of Stretching Food Resources}

Agencies were asked whether their feeding programs ever had to limit food distribution in order to provide food to all clients and, if so, how often. The results follow. Table 4.2.1 shows the results of pantries.

Table 4.2.1

\section{FREQUENCY OF STRETCHING FOOD RESOURCES IN PANTRIES}

\begin{tabular}{|c|c|c|c|c|}
\hline $\begin{array}{l}\text { During 2009, How Often Did } \\
\text { the Program Have to Reduce } \\
\text { Meal Portions or Reduce the } \\
\text { Quantity of Food in Food } \\
\text { Packages Because of a Lack } \\
\text { of Food? }\end{array}$ & $\begin{array}{l}\text { Clay } \\
\text { County }\end{array}$ & $\begin{array}{l}\text { Webster } \\
\text { County }\end{array}$ & $\begin{array}{c}\text { Pantry Programs } \\
\text { (Both) }\end{array}$ & $\begin{array}{c}\text { National Ave. } \\
\text { Pantry Programs* }\end{array}$ \\
\hline Never & $17 \%$ & $0 \%$ & $13 \%$ & $35 \%$ \\
\hline Rarely & $16 \%$ & $100 \%$ & $37 \%$ & $40 \%$ \\
\hline Subtotal & $34 \%$ & $100 \%$ & $50 \%$ & $75 \%$ \\
\hline Sometimes & $50 \%$ & $0 \%$ & $37 \%$ & $23 \%$ \\
\hline Always & $16 \%$ & $0 \%$ & $13 \%$ & $2 \%$ \\
\hline Subtotal & $66 \%$ & $0 \%$ & $50 \%$ & $25 \%$ \\
\hline SAMPLE SIZE (N) & 6 & 2 & 8 & 23,842 \\
\hline
\end{tabular}

SOURCE: This table was constructed based on usable responses to Question 13 of the agency survey.

Notes: The percentages presented in this table are based only on usable responses, excluding missing, don’t know, and refusal responses.

*Data for national averages comes from the Hunger in America 2010 study performed by Feeding America.

Results for kitchens are below in Table 4.2.2. 
Table 4.2.2

\section{FREQUENCY OF STRETCHING FOOD RESOURCES IN KITCHENS}

\begin{tabular}{|c|c|c|c|c|}
\hline $\begin{array}{l}\text { During 2009, How Often Did } \\
\text { the Program Have to Reduce } \\
\text { Meal Portions or Reduce the } \\
\text { Quantity of Food in Food } \\
\text { Packages Because of a Lack } \\
\text { of Food? }\end{array}$ & $\begin{array}{l}\text { Clay } \\
\text { County }\end{array}$ & $\begin{array}{l}\text { Webster } \\
\text { County }\end{array}$ & $\begin{array}{l}\text { Kitchen Programs } \\
\text { (Both) }\end{array}$ & $\begin{array}{l}\text { National Ave. } \\
\text { Kitchen Programs* }\end{array}$ \\
\hline Never & $33 \%$ & $0.0 \%$ & $20 \%$ & $62 \%$ \\
\hline Rarely & $33 \%$ & $100.0 \%$ & $60 \%$ & $26 \%$ \\
\hline Subtotal & $66 \%$ & $100.0 \%$ & $80 \%$ & $88 \%$ \\
\hline Sometimes & $34 \%$ & $0.0 \%$ & $0 \%$ & $11 \%$ \\
\hline Always & $0.0 \%$ & $0.0 \%$ & $20 \%$ & $1 \%$ \\
\hline Subtotal & $34 \%$ & $0.0 \%$ & $20 \%$ & $12 \%$ \\
\hline SAMPLE SIZE (N) & 3 & 2 & 5 & 6,064 \\
\hline
\end{tabular}

SOURCE: This table was constructed based on usable responses to Question 13 of the agency survey.

NOTES: The percentages presented in this table are based only on usable responses, excluding missing, don't know, and refusal responses.

* Data for national averages comes from the Hunger in America 2010 study performed by Feeding America.

Table 4.2.3 presents the results of all programs in Clay and Webster counties that stretch food resources in order to provide to all clients. 
Table 4.2.3

\section{FREQUENCY OF STRECTHING FOOD RESOURCES IN ALL PROGRAMS IN CLAY AND WEBSTER}

\begin{tabular}{cccc}
$\begin{array}{c}\text { During 2009, How Often Did the Program } \\
\text { Have to Reduce Meal Portions or Reduce } \\
\text { the Quantity of Food in Food Packages } \\
\text { Because of a Lack of Food? }\end{array}$ & $\begin{array}{c}\text { Clay } \\
\text { County }\end{array}$ & $\begin{array}{c}\text { Webster } \\
\text { County }\end{array}$ & $\begin{array}{c}\text { All Programs } \\
\text { (Clay and Webster) }\end{array}$ \\
Never & $22 \%$ & $0 \%$ & $15 \%$ \\
Rarely & $22 \%$ & $100 \%$ & $46 \%$ \\
Subtotal & $44 \%$ & $100 \%$ & $61 \%$ \\
Sometimes & $44 \%$ & $0 \%$ & $31 \%$ \\
Always & $11 \%$ & $0 \%$ & $8 \%$ \\
Subtotal & $56 \%$ & $0 \%$ & $39 \%$ \\
\hline & & & 13 \\
\hline SAMPE SIZE (N) & 9 & 4 & \\
\hline
\end{tabular}

SOURCE: This table was constructed based on usable responses to Question 13 of the agency survey.

NotEs: The percentages presented in this table are based only on usable responses, excluding missing, don't know, and refusal responses.

*Data for national averages comes from the Hunger in America 2010 study performed by Feeding America.

According to the results, 66\% of pantries in Clay County sometimes or always reduced the quantity of their food quantities. This compares to a national average of $27 \%$ of pantries. Webster County was quite the opposite with $0 \%$ reporting sometimes or always reducing meal quantities. Kitchens were much lower in both counties with $66 \%$ in Clay County and 100\% in Webster County rarely or never reducing food quantities. 
The following are responses about food supplies:

"We always reduce the amount of food."

"We have to cut off some food at times."

“We can’t give every single person everything...we have to limit what we give."

For some pantries, limiting and/or reducing the amount of food given out is a

weekly occurrence. If the program doesn't have a constant stream of funding, they again

work week to week, giving out what they can. Other programs, especially kitchens, have an established budget that allows them to predict their weekly or monthly capacity. 


\subsection{Programs That Turned Clients Away}

Agencies were asked whether their programs had to turn clients away within the past year for any reason. Respondents that answered yes were asked how many and for what reason(s). Table 4.3.1 shows the responses of pantries in Clay and Webster counties compared to the national average.

Table 4.3.1

PANTRIES THAT TURNED CLIENTS AWAY

\begin{tabular}{|c|c|c|c|c|}
\hline & $\begin{array}{l}\text { Clay } \\
\text { County }\end{array}$ & $\begin{array}{l}\text { Webster } \\
\text { County }\end{array}$ & $\begin{array}{l}\text { Pantry } \\
\text { Programs } \\
\text { (Both) }\end{array}$ & $\begin{array}{c}\text { National } \\
\text { Ave. Pantry } \\
\text { Programs* }\end{array}$ \\
\hline \multicolumn{5}{|l|}{$\begin{array}{l}\text { Did the program turn away clients } \\
\text { in the past year? }\end{array}$} \\
\hline Yes & $50 \%$ & $33 \%$ & $44 \%$ & $27 \%$ \\
\hline No & $50 \%$ & $67 \%$ & $56 \%$ & $73 \%$ \\
\hline Total & $100 \%$ & $100 \%$ & $100 \%$ & $100 \%$ \\
\hline SAMPLE (N) & 6 & 3 & 9 & 23,842 \\
\hline $\begin{array}{l}\text { Average Number of Clients } \\
\text { Turned Away in the Past Year }\end{array}$ & 6.5 & 20 & 11 & 72 \\
\hline $\begin{array}{c}\text { Median Number of Clients Turned } \\
\text { Away in the Past Year }\end{array}$ & 6.5 & 20 & 10 & 15 \\
\hline $\begin{array}{l}\text { SAMPLE (N) Programs providing a } \\
\text { valid number of clients who where } \\
\text { turned away }\end{array}$ & 2 & 1 & 3 & 3,121 \\
\hline \multicolumn{5}{|l|}{ Reasons for Turning Clients Away } \\
\hline Lack of Food Resources & $33 \%$ & $0 \%$ & $25 \%$ & $45 \%$ \\
\hline $\begin{array}{c}\text { Services Needed Not Provided } \\
\text { by the Program }\end{array}$ & $0.0 \%$ & $100 \%$ & $25 \%$ & $20 \%$ \\
\hline $\begin{array}{l}\text { Clients were ineligible or could } \\
\text { not prove Eligibility }\end{array}$ & $67 \%$ & $100 \%$ & $75 \%$ & $34 \%$ \\
\hline $\begin{array}{l}\text { Clients Came More Often than } \\
\text { Programs Rules Allow }\end{array}$ & $0.0 \%$ & $100 \%$ & $25 \%$ & $50 \%$ \\
\hline $\begin{array}{l}\text { Clients Exhibited Drug, Alcohol, } \\
\text { or Behavior Problem }\end{array}$ & $0.0 \%$ & $0 \%$ & $0 \%$ & $16 \%$ \\
\hline $\begin{array}{l}\text { Clients Lived Outside } \\
\text { Service Area }\end{array}$ & $0.0 \%$ & $100 \%$ & $25 \%$ & $41 \%$ \\
\hline
\end{tabular}


Clients did not have ID Required by Program

Client's income exceeded program guidelines

SAMPLE SIZE (N)

$0.0 \%$
$33.3 \%$

3
$0.0 \%$

$100.0 \%$

1
$27 \%$

$20 \%$

5,622

SOURCE: This table was constructed based on usable responses to Question 9, 10 and 12 of the agency survey.

NoTES: The percentages presented in this table are based only on usable responses, excluding missing, don't know, and refusal responses.

*Data for national averages comes from the Hunger in America 2010 study performed by Feeding America.

According to the data, $50 \%$ of pantries in Clay County and 33\% of pantries in Webster County turned clients away in 2009. The national average for all pantries was 27\%. Other results include:

- The average total number of clients turned away in 2009 was 6.5 in Clay and 20 in Webster, compared to a national average of 72.

- The most common reason for turned clients away was because clients were ineligible.

- A lack of food resources accounted for the reason 33\% of pantries in Clay County turned clients away.

- $33 \%$ of pantries in Clay County turned clients away because their income exceeded program guidelines for clients.

Table 4.3.2 shows the data for kitchens in Clay and Webster counties that turned clients away. 
Table 4.3.2

KITCHENS THAT TURNED CLIENTS AWAY

\begin{tabular}{|c|c|c|c|c|}
\hline & $\begin{array}{l}\text { Clay } \\
\text { County }\end{array}$ & $\begin{array}{l}\text { Webster } \\
\text { County }\end{array}$ & $\begin{array}{l}\text { Kitchen } \\
\text { Programs } \\
\text { (Both) }\end{array}$ & $\begin{array}{l}\text { National } \\
\text { Ave. } \\
\text { Kitchen } \\
\text { Programs* }\end{array}$ \\
\hline \multicolumn{5}{|l|}{$\begin{array}{l}\text { Did the program turn away clients } \\
\text { in the past year? }\end{array}$} \\
\hline Yes & $0 \%$ & $100 \%$ & $40 \%$ & $10 \%$ \\
\hline No & $100 \%$ & $0 \%$ & $60 \%$ & $90 \%$ \\
\hline Total & $0 \%$ & $100 \%$ & $100 \%$ & $100 \%$ \\
\hline SAMPLE (N) & 3 & 2 & 5 & 6,064 \\
\hline $\begin{array}{l}\text { Average Number of Clients } \\
\text { Turned Away in the Past Year }\end{array}$ & n.a. & n.a. & n.a. & 72. \\
\hline $\begin{array}{c}\text { Median Number of Clients Turned } \\
\text { Away in the Past Year }\end{array}$ & n.a. & n.a. & n.a. & 10. \\
\hline $\begin{array}{l}\text { SAMPLE (N) Programs providing a } \\
\text { valid number of clients who where } \\
\text { turned away }\end{array}$ & n.a. & n.a. & n.a. & 309 \\
\hline \multicolumn{5}{|l|}{ Reasons for Turning Clients Away } \\
\hline Lack of Food Resources & n.a. & $100 \%$ & $100 \%$ & $45 \%$ \\
\hline $\begin{array}{c}\text { Services Needed Not Provided } \\
\text { by the Program }\end{array}$ & n.a. & $0 \%$ & $0 \%$ & $18 \%$ \\
\hline $\begin{array}{l}\text { Clients were ineligible or could } \\
\text { not prove Eligibility }\end{array}$ & n.a. & $0 \%$ & $0 \%$ & $14 \%$ \\
\hline $\begin{array}{l}\text { Clients Came More Often than } \\
\text { Programs Rules Allow }\end{array}$ & n.a. & $0 \%$ & $0 \%$ & $6 \%$ \\
\hline $\begin{array}{l}\text { Clients Exhibited Drug, Alcohol, } \\
\text { or Behavior Problem }\end{array}$ & n.a. & $0 \%$ & $0 \%$ & $45 \%$ \\
\hline $\begin{array}{l}\text { Clients Lived Outside } \\
\text { Service Area }\end{array}$ & n.a. & $0 \%$ & $0 \%$ & $7 \%$ \\
\hline $\begin{array}{c}\text { Clients did not have ID Required } \\
\text { by Program }\end{array}$ & n.a. & $0 \%$ & $0 \%$ & $5 \%$ \\
\hline $\begin{array}{l}\text { Client’s income exceeded } \\
\text { program guidelines }\end{array}$ & n.a. & $0 \%$ & $0 \%$ & $4 \%$ \\
\hline SAMPLE SIZE (N) & 0 & 2 & 2 & 472 \\
\hline
\end{tabular}

SOURCE: This table was constructed based on usable responses to Question 9, 10 and 12 of the agency survey. 
NOTES: The percentages presented in this table are based only on usable responses, excluding missing, don't know, and refusal responses.

n.a. = not available

*Data for national averages comes from the Hunger in America 2010 study performed by Feeding America.

$0 \%$ of kitchens in Clay County and $100 \%$ in Webster reported turning clients away in 2009. The national average for kitchens turning clients away is $10 \%$. A lack of food resources was the strongest reason reported for turning clients away in Webster County at $100 \%$.

Next, Table 4.3.3 shows all feeding programs in Clay and Webster counties that turned clients away during the past year.

Table 4.3.3

ALL FEEDING PROGRAMS THAT TURNED CLIENTS AWAY

\begin{tabular}{cccc}
\hline $\begin{array}{c}\text { Clay } \\
\text { Did the program turn away clients } \\
\text { in the past year? }\end{array}$ & $\begin{array}{c}\text { Webster } \\
\text { County }\end{array}$ & $\begin{array}{c}\text { All Programs } \\
\text { (Clay and Webster }\end{array}$ \\
Yes & $33 \%$ & $60 \%$ & $43 \%$ \\
No & $67 \%$ & $40 \%$ & $57 \%$ \\
Total & $100 \%$ & $100 \%$ & $100 \%$ \\
SAMPLE (N) & 9 & 5 & 14 \\
Average Number of Clients & 6.5 & 20 & 10 \\
$\begin{array}{c}\text { Turned Away in the Past Year } \\
\text { Median Number of Clients Turned }\end{array}$ & & & \\
Away in the Past Year & 6.5 & 20 & 3 \\
$\begin{array}{c}\text { SAMPLE (N) Programs providing a } \\
\text { valid number of clients who where } \\
\text { turned away }\end{array}$ & 2 & & \\
Reasons for Turning Clients Away & & & \\
\hline
\end{tabular}




\begin{tabular}{cccc}
\hline $\begin{array}{c}\text { Lack of Food Resources } \\
\text { Services Needed Not Provided } \\
\quad \text { by the Program }\end{array}$ & $33 \%$ & $67 \%$ & $50 \%$ \\
$\begin{array}{c}\text { Clients were ineligible or could } \\
\text { not prove Eligibility }\end{array}$ & $33 \%$ & $33 \%$ & $17 \%$ \\
$\begin{array}{c}\text { Clients Came More Often than } \\
\quad \text { Programs Rules Allow } \\
\text { Clients Exhibited Drug, Alcohol, } \\
\quad \text { or Behavior Problem } \\
\quad \begin{array}{c}\text { Clients Lived Outside } \\
\text { Service Area }\end{array}\end{array}$ & $0 \%$ & $33 \%$ & $33 \%$ \\
$\begin{array}{c}\text { Clients did not have ID Required } \\
\text { by Program }\end{array}$ & $0 \%$ & $0 \%$ & $17 \%$ \\
$\quad \begin{array}{c}\text { Client's income exceeded } \\
\text { program guidelines }\end{array}$ & $67 \%$ & $0 \%$ & $0 \%$ \\
$\quad$ SAMPLE SIZE (N) & 3 & $33 \%$ & $0 \%$ \\
\hline
\end{tabular}

SOURCE: This table was constructed based on usable responses to Question 9, 10 and 12 of the agency survey.

NOTES: The percentages presented in this table are based only on usable responses, excluding missing, don't know, and refusal responses.

$33 \%$ of feeding programs in Clay and $60 \%$ of programs in Webster reported turning away clients in the past year. Other results follow.

- $33 \%$ of programs in Clay and $67 \%$ of programs in Webster cited a lack of food resources as the reason for turning clients away.

- $\quad 33 \%$ in both Clay and Webster counties said that they turned clients away because the clients were ineligible or could not prove eligibility.

- $67 \%$ of programs that turned clients away in Clay County reported that client's income exceeded program guidelines for clients turned away.

Pantries that had to stretch their food resources often fell short. 50.0\% of pantries in Clay and 33.3\% of pantries in Webster County had turned clients away. Of those turning clients away, 33.3\% of pantries in Clay cited lack of food resources as the reason. 
Other reasons for turning clients away include clients exceeding income guidelines or clients could not provide verification of income. While these reasons may not seem to directly support that pantries are struggling to acquire food, note that only USDA commodities require income verification. Pantries are allocated commodities based on their service population, so clients that do not meet income guidelines could still receive food from the general inventory. This leads us to the thought that pantries do not always have the right kind of food to distribute to their clients.

Kitchens in Clay County have had the opposite results of food pantries, with 0.0\% turning clients away. Webster County produced different results with $100.0 \%$ of kitchens having turned away clients during the past year, citing a lack of food resources as the reason. 


\subsection{Additional Resources Needed}

Agencies were asked whether more food was needed to adequately meet the demand of clients at their programs. Agencies that agreed that more food was needed were asked to explain how much more food or how many more meals were needed to adequately meet the demand. Table 4.4.1 shows the results for pantry needs compared to the national averages.

Table 4.4.1

\section{ADDITIONAL FOOD RESOURCES NEEDED PER WEEK FOR PANTRIES}

\begin{tabular}{ccccc}
\hline $\begin{array}{c}\text { Is More Food Needed to Adequately } \\
\text { Meet the Demand of Your Clients }\end{array}$ & Clay County & $\begin{array}{c}\text { Webster } \\
\text { County }\end{array}$ & $\begin{array}{c}\text { Pantry } \\
\text { Programs } \\
\text { (Both) }\end{array}$ & $\begin{array}{c}\text { National } \\
\text { Ave. Pantry } \\
\text { Programs** }\end{array}$ \\
Yes & $67 \%$ & $33 \%$ & $56 \%$ & $45 \%$ \\
No & $0 \%$ & $33 \%$ & $11 \%$ & $55 \%$ \\
Don't Know & $33 \%$ & $33 \%$ & $33 \%$ & n.a. \\
Total & $100 \%$ & $100 \%$ & $100.0 \%$ & $100 \%$ \\
SAMPLE SIZE (N) & 6 & 3 & 9 & 18,436 \\
Average Food Needed Per Week (lbs.) & 950 & 500 & 860 & 525 \\
Median Food Needed Per Week (lbs.) & 1000 & 500 & 1000 & 200 \\
Average Meals Needed Per Week & n.a. & n.a. & n.a. & n.a. \\
Median Meals Needed Per Week & n.a. & n.a. & n.a. & n.a. \\
\hline
\end{tabular}

SOURCE: This table was constructed based on usable responses to Question 14 of the agency survey.

NOTES: The percentages presented in this table are based only on usable responses, excluding missing and refusal responses.

n.a. = not available

** Data for national averages comes from the Hunger in America 2006 study performed by Feeding America. The 2010 study did not ask this question to pantries. 
The results show that $67 \%$ of pantries in Clay County and $33 \%$ of pantries in Webster County need additional food to meet the demand of clients each week. The national average for pantries is $45 \%$.

- $11 \%$ of pantries in both counties did not need additional food resources to meet client demand.

- $\quad$ The average for food resources needed was 950 lbs. in Clay County and 500 lbs. in Webster County. The national average is $525 \mathrm{lbs}$. and the median is $200 \mathrm{lbs}$.

Table 4.4.2 shows the results for kitchens compared to national averages.

Table 4.4.2

\section{ADDITIONAL FOOD RESOURCES NEEDED PER WEEK FOR KITCHENS}

\begin{tabular}{|c|c|c|c|c|}
\hline $\begin{array}{l}\text { Is More Food Needed to Adequately } \\
\text { Meet the Demand of Your Clients }\end{array}$ & Clay County & $\begin{array}{l}\text { Webster } \\
\text { County }\end{array}$ & $\begin{array}{c}\text { Kitchen } \\
\text { Programs } \\
\text { (Both) }\end{array}$ & $\begin{array}{c}\text { National } \\
\text { Ave. } \\
\text { Kitchen } \\
\text { Programs* }\end{array}$ \\
\hline Yes & $33.3 \%$ & $100.0 \%$ & $60 \%$ & $38 \%$ \\
\hline No & $0.0 \%$ & $0.0 \%$ & $0 \%$ & $62 \%$ \\
\hline Don’t Know & $66.7 \%$ & $0.0 \%$ & $40 \%$. & n.a. \\
\hline Total & $100.0 \%$ & $100.0 \%$ & $100 \%$ & $100 \%$ \\
\hline SAMPLE SIZE (N) & 3 & 2 & 5 & 6,063 \\
\hline Average Food Needed Per Week (lbs.) & n.a. & n.a. & n.a. & n.a \\
\hline Median Food Needed Per Week (lbs.) & n.a. & n.a. & n.a. & n.a. \\
\hline Average Meals Needed Per Week & n.a. & 30 & 30 & 137 \\
\hline Median Meals Needed Per Week & n.a. & 30 & 30 & 50 \\
\hline
\end{tabular}

SOURCE: This table was constructed based on usable responses to Question 14 of the agency survey.

NoTES: The percentages presented in this table are based only on usable responses, excluding missing and refusal responses. 
n.a. = not available

*Data for national averages comes from the Hunger in America 2010 study performed by Feeding America.

33.3\% of kitchens in Clay County and $100.0 \%$ of kitchens in Webster County report needing additional food resources to meet client demand. Neither of the counties reported that they did not need additional food.

Table 4.4.3 shows data for all programs in Clay and Webster counties in regards to additional food resources.

Table 4.4 .3

\section{ADDITIONAL FOOD RESOURCES NEEDED PER WEEK FOR ALL PROGRAMS IN CLAY AND WEBSTER}

\begin{tabular}{cccc}
\hline $\begin{array}{c}\text { Is More Food Needed to Adequately } \\
\text { Meet the Demand of Your Clients }\end{array}$ & $\begin{array}{c}\text { Clay County } \\
\text { Yes }\end{array}$ & $\begin{array}{c}\text { Webster } \\
\text { County }\end{array}$ & $\begin{array}{c}\text { All Programs } \\
\text { (Clay and Webster) }\end{array}$ \\
No & $06 \%$ & $60 \%$ & $57 \%$ \\
Don’t Know & $44 \%$ & $20 \%$ & $7 \%$ \\
Total & $100 \%$ & $100 \%$ & $36 \%$ \\
SAMPLE SIZE (N) & 9 & 5 & $100 \%$ \\
Average Food Needed Per Week (lbs.) & 950 & 500 & 14 \\
Median Food Needed Per Week (lbs.) & 1000 & 500 & 860 \\
Average Meals Needed Per Week & n.a. & 30 & 1000 \\
Median Meals Needed Per Week & n.a. & 30 & 30 \\
\hline
\end{tabular}

SOURCE: This table was constructed based on usable responses to Question 14 of the agency survey.

NOTES: The percentages presented in this table are based only on usable responses, excluding missing and refusal responses.

n.a. $=$ not available 
Of all programs in Clay County, 56\% reported that they needed additional food to meet the demand. For their programs, Webster County reported that $60 \%$ needed additional food.

- Only 7\% of all programs in both counties reported having enough food to meet the demand of weekly clients.

- The average food needed per week was $860 \mathrm{lbs}$. and 30 meals for both counties.

Administrators reported that $67 \%$ of pantries in Clay County and 33\% in Webster need more food to adequately meet the demand of their clients. This compares to a national average of $45 \%$ of pantries. Pantries in Clay County report that they need an average of 950 lbs. each week. Pantries in Webster County reported a need for an average 500 lbs. each week.

An interesting result evolved from the data, because $100 \%$ of kitchens in Webster County reported that they had adequate food supplies to meet the need, compared to a national average of 38\%. However, when they were asked if additional food resources were needed, programs reported an average of thirty meals each week were needed. Also, $100 \%$ of kitchens in Webster County turned clients away during the past year, citing a lack of food resources as the reason. From the beginning question, no kitchens in Webster County felt that the lack of food supplies threatened their existence, and kitchens in both counties reported that they had not reduced meal portions during the year. To account for this, the qualitative data from the interviews was reexamined. Here are some of the responses from administrators: 
"We have a waiting list for meals."

"A lot of them, they'll come here and eat and they'll go to these other places to get stuff

[more food].

"I think a lot of people could use two meals per day. A lot of people have asked for an extra meal. Just because they don't have the money."

Both kitchens in Webster County rely on government funding to operate and receive recurrent amounts of funding each month. Also, both programs offer home delivered meals to clients five days a week. From the interviews, the kitchens were able to support a limited amount of clients efficiently with a single meal. After those, they would be unable to keep up the entire demand of other clients. Clients may need two or more meals each day, but the structure of the kitchen is only set up to provide one. 


\subsection{Impact of Elimination of Food Bank}

Agencies were asked how much the elimination of the food bank would have on their programs. Table 4.5.1 shows the results for pantries.

Table 4.5.1

\section{IMPACT OF ELIMINATION OF FOOD BANK ON PANTRIES}

\begin{tabular}{ccccc}
\hline $\begin{array}{c}\text { Impact if the Food Bank was } \\
\text { Eliminated }\end{array}$ & Clay County & $\begin{array}{c}\text { Webster } \\
\text { County }\end{array}$ & $\begin{array}{c}\text { Pantry } \\
\text { Programs } \\
\text { (Both) }\end{array}$ & $\begin{array}{c}\text { National } \\
\text { Ave. Pantry } \\
\text { Programs* }\end{array}$ \\
No Impact at All & $0 \%$ & $0 \%$ & $0 \%$ & $1 \%$ \\
Minimal Impact & $0 \%$ & $0 \%$ & $0 \%$ & $6 \%$ \\
Significant Impact & $17 \%$ & $33 \%$ & $22 \%$ & $28 \%$ \\
Devastating Impact & $83 \%$ & $67 \%$ & $78 \%$ & $63 \%$ \\
Unsure & $0 \%$ & $0 \%$ & $0 \%$ & $2 \%$ \\
SAMPLE SIZE (N) & 6 & 3 & & 23,842 \\
\hline
\end{tabular}

SOURCE: This table was constructed based on usable responses to Question 18 of the agency survey.

NOTES: The percentages presented in this table are based only on usable responses, excluding missing, don’t know, and refusal responses.

*Data for national averages comes from the Hunger in America 2010 study performed by Feeding America.

From Clay County, $83 \%$ of pantries and 67\% of pantries in Webster County indicate that the elimination of the local food bank would have a devastating impact on their feeding program. This compares to a national average of $63 \%$.

- $17 \%$ of pantries in Clay County and $33 \%$ of pantries in Webster County indicate that the elimination of the local food bank would have a significant impact on their feeding program. 
Table 4.5.2 shows the results for kitchens in Clay and Webster counties versus the national average.

Table 4.5.2

IMPACT OF ELIMINATION OF FOOD BANK ON KITCHENS

\begin{tabular}{ccccc}
\hline $\begin{array}{c}\text { Impact if the Food Bank was } \\
\text { Eliminated }\end{array}$ & Clay County & $\begin{array}{c}\text { Webster } \\
\text { County }\end{array}$ & $\begin{array}{c}\text { Kitchen } \\
\text { Programs } \\
\text { (Both) }\end{array}$ & $\begin{array}{c}\text { National } \\
\text { Ave. } \\
\text { Kitchen } \\
\text { Programs* }\end{array}$ \\
No Impact at All & $0 \%$ & $0 \%$ & $0 \%$ & $5 \%$ \\
Minimal Impact & $33 \%$ & $100 \%$ & $60 \%$ & $14 \%$ \\
Significant Impact & $33 \%$ & $0 \%$ & $20 \%$ & $35 \%$ \\
Devastating Impact & $33 \%$ & $0 \%$ & $20 \%$ & $42 \%$ \\
Unsure & $0 \%$ & $0 \%$ & $0 \%$ & $5 \%$ \\
SAMPLE SIZE (N) & 3 & 2 & 5 & 6,064 \\
\hline
\end{tabular}

SOURCE: This table was constructed based on usable responses to Question 18 of the agency survey.

NoTES: The percentages presented in this table are based only on usable responses, excluding missing, don't know, and refusal responses.

* Data for national averages comes from the Hunger in America 2010 study performed by Feeding America.

33\% of kitchens in Clay County and 100\% of kitchens in Webster County report that the elimination of the local food bank would have a minimal impact on their feeding program.

- $33 \%$ of kitchens in Clay reported that the elimination of the food bank would have devastating impacts on their program. 
Table 4.5.3 shows the results for all programs in Clay and Webster counties.

Table 4.5.3

IMPACT OF ELIMINATION OF FOOD BANK ON ALL PROGRAMS

\begin{tabular}{cccc}
\hline $\begin{array}{c}\text { Impact if the Food Bank was } \\
\text { Eliminated } \\
\text { No Impact at All }\end{array}$ & Clay County & $\begin{array}{c}\text { Webster } \\
\text { County }\end{array}$ & $\begin{array}{c}\text { All Programs } \\
\text { (Clay and Webster) }\end{array}$ \\
Minimal Impact & $0 \%$ & $0 \%$ & $0 \%$ \\
Significant Impact & $11 \%$ & $40 \%$ & $21 \%$ \\
Devastating Impact & $22 \%$ & $20 \%$ & $21 \%$ \\
Unsure & $67 \%$ & $40 \%$ & $57 \%$ \\
SAMPLE SIZE (N) & $0 \%$ & $0 \%$ & $0 \%$ \\
\hline
\end{tabular}

SOURCE: This table was constructed based on usable responses to Question 18 of the agency survey.

NoTES: The percentages presented in this table are based only on usable responses, excluding missing, don't know, and refusal responses.

$67 \%$ of all programs in Clay County and $40 \%$ of programs in Webster County report that the elimination of the local food bank would have devastating results.

- $57 \%$ of all programs in both counties report that the elimination would have devastating results.

Finally, when agencies were asked to measure the impact of the loss of the local food bank, $83 \%$ of pantries in Clay and $67 \%$ of pantries in Webster responded the impact would be devastating. For many of these programs, the food bank is the only sufficient source for food that they have access too. The problem resulting from low food access carries over to feeding programs, who cannot afford the travel and expense to go out of town them selves to purchase food. The food bank's ability to delivery food into the county makes a significant case for their importance. 
Kitchens had a more positive response with only 33\% citing a devastating impact in Clay County. All kitchens in Webster County responded that the loss of the food bank would only minimally impact their program. On average, $42 \%$ of kitchens felt that the loss of the food bank would devastate their service. Some kitchens purchase food from food services companies, such as U.S. Foodservice, which allows them to be less dependent on the food bank. Again, the funding factor comes into the situation because these kitchens are able to predict their monthly budget.

\section{Results Summary}

Overall, 83\% of pantries in Clay County and 100\% in Webster County reported have one or more problems that threaten their existence. Kitchens provide similar results with 67\% in Clay County and 100\% in Webster County facing one or more problems. Many of the programs stretch their resources in order to survive, however, sometimes this is not enough and they must turn away clients. While the main two problems centered on funding and food supplies, information from the interviews about the area provide a better understanding of why these issues exist.

First, the analysis will look at Webster County, the severely low access county. Webster County has a successful history of extracting natural resources through the logging, mining and natural gas industries. However, since the county infrastructure was built around those resources, once they diminished, the outside support and employment left the area.

The following are remarks from program administrators:

"In Webster County, there are so few resources.... No Salvation Army...No United Way...No Red Cross.”

“Jobs are horrible." 
"The young people that live here are the ones that are struggling."

"The amount of money we get is based on how many people are receiving unemployment...the people in this county have been receiving unemployment for so long...they are no longer drawing, so they are not even counted anymore."

"People are having to drive out of county now and even the logging people are having to go out of state."

"We had a grocery store here...well it was never stocked...there was very little there and they eventually closed. The only place you could buy milk and bread was at the filling station and then you pay quite a bit for it."

"People here, are the people we would be doing the food drive for."

Employment, public resources and access to adequate food resources are all significant issues that affect both the clients and feeding programs in Webster County. Those programs that rely on donations from the community struggle to keep up with the demand because the people that they look to for help are the same ones that need it. Programs that rely on outside resources, such as government funds or grants, have a limited amount of security for their program.

As quoted above, many types of government aid are based on unemployment data. Many people began receiving benefits when the major industries left the county, and after exhausting unemployment, became part of the non-working class. In Webster County, an astounding $56 \%$ of the population are no longer in the labor force (B \& E WVU). This part of the population is now not bringing resources into the county.

Low employment and few companies have contributed to a small tax base for communities to draw on for public support. Community-based programs have little opportunity to receive funds from the county or town districts that they operate in because they have no funds to give. Without funds from their citizens or county, feeding programs must look outside to bring funding and food into their community. 
From the interviews, administrators have confirmed that access to adequate supplies of food is a "chronic problem that's local". At its peak, Webster County had two small grocers that provided for the county. The stores were separated by 10-15 miles of winding, mountainous roads. Currently, there is only one operating grocery store in the county, located in the county seat of Webster Springs. Residents must travel 10-30 miles or farther to reach it. Those that cannot afford to travel that far or do not have the ability to travel rely more and more on the feeding programs in the area. The only public transportation available is limited to senior citizens on weekdays.

Now, the study will examine Clay County our low access county. Clay County is part of the urban-rural area bordering the state capitol. It is considered part of the metropolitan area surrounding the Kanawha Valley because of its proximity, but is rural in every other possible dimension. The only benefit to its location is access to Interstate 79, which allows travel towards Charleston and Clarksburg.

Administrators had this to say about the local area:

"Very poor, not a lot of jobs, many people go outside of the county for employment."

"Everything is 25-30 minutes away."

"It's hard to get to everybody, because everybody's so far apart from each other."

"The prices at that store are so high that people that have to shop there can't make their money go very far."

Clay County, like Webster, has little resources and few opportunities for employment to offer its residents. Residents that are employed take advantage of access to jobs in nearby Charleston, while also purchasing their groceries and other supplies 
there. Those that do not work or are unemployed rely on the resources at hand, which are few.

Feeding programs in Clay County have greater prospects for support, benefiting from donations from those that work out of county. In county, coal mining jobs are slowly decreasing but still available for a few decent paying positions. The coal industry also provides some tax base for town and county government to support activities. Nevertheless, after coal and out of county jobs there is a steep decline of employment for the rest of the county.

Communities and businesses are often separated by 15-25 miles of roads. Clay County currently has one grocery store, and as stated above, "the prices at that store are so high”. Those that have money often travel 25-30 miles to Charleston to shop, or rely on family members to bring them items from those areas. Those that cannot afford travel, rely on the feeding programs.

Many of the feeding programs in Clay offer home delivery services, such as meals and packages of food. Administrators agreed that it was impossible for everyone in need to make it to their site, especially the elderly and young families with no jobs. But even, with the funding, it is difficult to reach everyone. One client may live five miles up one rural road, and the next five miles up another. Time and distance seem to work against the programs as much as anything. Public transportation is unavailable, and many families carpool with someone to collect food at the pantry. One administrator stated, "Families save up money by carpooling, so that they can take longer trips for doctor visits.” 


\section{Discussion}

Emergency food providers in the two counties sampled in West Virginia struggle to a greater extent than the national average. According to the indicators chosen, programs in Clay County and Webster County exceed the national average percentages in almost all categories including problems that threaten the programs existence, turning clients away, stretching food resources and need of additional resources. Funding is the largest cause of instability, with food supplies a close second. Pantries are more at-risk than kitchens to become inoperative. This can be explained by the fact that many of the kitchens are combined with senior care programs or other state-funded agencies. However, the relationships that kitchens hold with government funding is sensitive and any budget reductions could affect them greatly.

Programs in these two counties are disadvantaged due to little or no economic resources, fragmented infrastructures and a high dependence on community or government safety net programs. Overall, both counties struggle with food access and funding at higher percentages than the national average. Feeding programs often operate from donations from the public, with supplemental funding from grants or other sources. However, in the case of these two counties, neither county has sufficient access to food or funding sources to sustain a long-term increase in need. The majority of residents in both counties cannot afford to contribute to the programs, as they are often the beneficiaries. As many of the program administrators admitted, many of the people in their area are too poor to give, leaving fewer and fewer donors to contribute.

Food pantries are seeing more and more clients, with 89\% reporting an increase in clients in the past three years. Pantries in Clay County are being forced to reduce the 
quantities of food boxes, with 67\% reporting that they did in 2009. Kitchens fare a little better, even though 80\% report an increase in clients served. Programs in Webster County have managed better with food resources, with $100 \%$ reporting that they rarely have had to reduce meal portions or food quantities.

Overall, emergency food providers in both counties appear to struggle more than the national average, but for different reasons. Pantries and kitchens both struggle with funding, but the ability to receive government funding through providing extra services benefits kitchens in both counties. Pantries have no choice but to reach out to their community for support.

Programs in Webster County have endured this hardship for many years, almost to where they have adapted to survive. Access to food has always been a problem due to the confined nature of the county. Pantries rely heavily on USDA commodities or large outside faith-based parent organizations for support. They have little to no public support, and without government assistance or outside influences, their programs would fail. There are no large companies or corporations to seek support, leaving few opportunities for help. Volunteer support is low, and organizations are mostly run by elder staff or volunteers with no succession plan when they are unable to operate the programs.

Programs in Clay County are struggling to adapt to new changes in the economic climate, yet they do have a greater potential than Webster to sustain their programs. A major interstate runs through the county, yet, most of the residents remain geographically isolated. Those that do have financial security work out of county but do contribute to the tax base through earnings and are able to contribute to these feeding programs. As a result, feeding programs in Clay have a stronger support structure for donations than 
Webster County. Staff and volunteers are younger, with almost twice as many programs in Clay than Webster.

Overall, Clay County and Webster County differ on their largest challenges or threats to their programs. Programs in Clay County, the low access county, are able to access the food more frequently than Webster County programs, but only when the funding is available. Program administrators combine program trips with personal trips to purchase food at the nearest large grocer, which is nearly forty miles away. Funding is often the biggest concern for programs in Clay County.

In Webster County, the biggest challenge for their programs is access to the food. While funding is also a concern, reliable access to food presents the biggest threat. The residents or programs do not have access to a consistent stream of healthy food (e.g. produce, dairy, whole-grain breads) due primarily to the lack of transportation into the county. Feeding programs are limited to their monthly distribution from the Food Bank and special trips they can take to pick up extra food.

\section{Conclusion}

This study addressed three research questions: 1) How do emergency food providers in West Virginia compare to those elsewhere in the country in relation to overall stability and challenges faced? 2) Do provider challenges differ between the low access and severely low access counties? If so, how? 3) What are the implications for addressing hunger in West Virginia?

The data showed that emergency food providers in West Virginia appear to be less stable and face more challenges than providers elsewhere in the country based on the data collected by this study. Food providers in Clay and Webster counties showed higher 
percentages of having threatening problems, stretching food resources, turning clients away, and needing additional resources. Food providers face severe problems with funding and food access, while being unable to sustain local infrastructures that could provide alternative resources.

Of the pantries in Webster and Clay counties, 89\% faced one or more problems that threaten the existence of their programs, compared to a national average of $67 \%$. Of the kitchens, $80 \%$ faced one or more problems. Administrators cited a lack of money, food and manpower as primary reasons that their programs are threatened. Their programs "barely have enough [food]" to operate their programs now, much less any substantial long-term increases.

Programs face local and statewide challenges that include food access, lack roads and transportation, local economic systems, employment, and an aging senior population. Many programs attempt to provide food to those without transportation, especially the elderly, but cannot provide adequate services due to difficult weather and roads to reach them. The economic systems declined with the natural resources industry and took with it employment and local merchants.

Food providers in low access counties and severely low access counties show similar results as far as overall stability. The main difference is the primary challenge that they face as a threat to their existence. Clay County, the low access county, showed funding as the primary concern to programs. Many of the programs felt that once they had adequate funding they would be more capable of acquiring food, even though they would still have to travel 35-45 miles to purchase it. Programs in Webster County, a severe low access county, showed that food was the primary threat. Even with adequate 
funding, programs did not feel that they would be able to access enough food due to the physical barriers surrounding the county. The lack of public transportation to access to healthy foods presents an overwhelming challenge for residents of Webster County.

Finally, there is no one solution for addressing hunger in West Virginia. Rural counties provide a complicated framework due to the lack of resources and fragmented infrastructures. These areas will always need some type of assistance, whether government or non-profit. Both Clay and Webster counties provide prime examples of areas that no longer have resources to be sustainable on their own.

Many of the problems faced by feeding programs can be resolved. On the local level, emergency food providers must adapt to become more self-sufficient. Some possible solutions could be to create cross training workshops between feeding programs that are successful and those that are struggling. Providers would benefit from more training that directly addresses the issues they are facing in their community. Many programs are operated by volunteer staff from faith-based organizations, and have little education about hunger relief or non-profit management. Trainings that address capacity building, volunteer training, food safety, fundraising, annual planning and grant writing would aid programs small and large. Programs may have resources readily available without realizing it.

Through agency capacity building, programs may be able to relieve some of the financial stress they experience. Administrators that are trained in grant writing can apply for government and private funding to help offset the expenses of their program. There are many foundations, charitable giving programs and government grants for which relief 
programs are eligible. Programs would be able to reach outside of their county and even state to apply for funds, relieving some of the burden that the county experiences.

Training in fundraising would also benefit feeding programs; however, it may be limited. Many programs are reactive in a sense that they wait until they need funding to purchase food. A more proactive approach through fundraising would allow programs to reach out for donations all of the time, even when there is a surplus. Fundraising may be limited within the local communities, because as one administrator stated, "People here, are the people we would be doing the food drive for." While there may not be many strong sources of funding through the community, it should still be a part of the program. Agencies can work together to create regional events for fundraising or advocacy. It is important that agencies are capable of networking together, so that they are not duplicating services to the same client population in an area. It would stand to reason that if there were two food providers within a short distance of each other, it would be more beneficial to the clients if they provided somewhat different services (e.g. nutritional counseling or employment training) instead of both providing the same service. Through networking, providers may be able to reduce the cost and amount of food needed to provide services. Strategic planning to close the communication gaps between similar organizations would help local communities deliver effective programs.

Feeding programs will find it necessary to broaden their services and develop new channels for funding and food access. The communities themselves will also need to expand on the available local food resources through programs such as farmers markets, food co-ops, and community gardens. Many farmers markets or roadside stands are now eligible to accept EBT funds that are processed through portable credit card machines. 
These programs allow SNAP participants to use their funds to purchase healthier, locally grown foods. Community gardens have been successful in metro areas and could be altered to fit the needs of rural communities. Participants receive a portion of each season's harvest in return for work in the garden. Programs such as these provide opportunities for self-sufficiency in some small communities.

On the state level, West Virginia may consider forming a statewide and/or regional Food Policy Council to address hunger issues. The U.S. government uses various agencies to deal with food-related issues, which severely limits the ability to coordinate responsibilities and broaden food access. A Food Policy Council is group of vested stakeholders, usually representatives from various sectors of the food system in the state. This council serves as a workgroup among different interests within the food community and, following research and discussion, makes recommendations for improving the efficiency of the food delivery system and access to nutritious food in the community. In Ohio, the Ohio Food Policy Council researched and developed tools to understand the efficacy of food access interventions and the programs that were successful (Castellano 2010). Currently, no Food Policy Council exists in West Virginia.

Food Policy Councils have been successful in developing relationships between food providers and those in need of the resources. Many councils cover large cities or large areas of rural states. Some examples of their works include: 1)The Mercer County (NJ) Food Forum created an online social networking site around local food issues ; 2) the Cleveland-Cayahoga Food Policy Council sponsored a Regional Food Congress to foster better communication between organizations (government agencies and businesses), farmers, processors, consumers and businesses (Harper et al. 2009). The 
Seattle King County Food Policy Council helped develop a statewide coalition to pass a Local Farms, Healthy Kids bill, which set up state infrastructure for farm to school programs and to get EBT in farmers markets (Harper et al. 2009). Food Policy Councils have grown from the first one 30 years ago in Knoxville, Tennessee, to over 110 councils in the United States and Canada.

A Food Policy Council would provide a forum for community members to discuss the issues and network together on a plan to achieve hunger free communities.

Stakeholders include food banks, government assistance programs (SNAP, Food Stamps, and WIC), school nutrition programs, businesses, county officials, faith-based organizations, and non-profit outreach organizations. They also conduct research to identify barriers to obtaining adequate food and identify organizations that can fulfill gaps in services.

A Food Policy Council in West Virginia would provide the groundwork to begin the second step needed, which is to conduct a gap analysis of how effective all organizations are at providing food sources (e.g. food banks, feeding programs, grocers) in West Virginia. A gap analysis would gather statistical data to establish where food service gaps are in the food network by county and explain why those gaps exist in the current system. This data can be used to determine the need for specific areas that need improved food access. The gap analysis tool can help identify ways multiple organizations can collaborate to address hunger needs on a local level.

According to Blanchard and Lyson (2002) only five counties in West Virginia were considered to suffer from severely low levels of food access. Other counties show signs of more success with food access and economic systems. According to the 
Appalachian Regional Commission, twenty-one counties are in the transitional stage according to economic indicators. These counties are showing increases in income, employment and overall financial well-being. A gap analysis tool would allow us to see what these counties are doing that differs from the severely distressed and low access counties, and whether physical locations can be compensated for.

State policymakers would be able to use information provided by a gap analysis to justify state and federal funding towards transportation, economic development and stronger social services. The counties involved in this study would benefit from an increase in funding towards public transportation, such as buses and funding toward providers that deliver their services to individuals homes. Economic development grants would entice small business owners to open grocery stores and farmers markets in rural underserved areas. Tax incentives for business owners would also allow them time to develop a consumer base and bring in healthier foods.

Other possible solutions include creating an up-to-date database within West Virginia (or the Food Policy Council network) that can be accessed by all partners. This would create an understanding that all counties are striving for the same goals. An informational database for all partners could be used to inform clients who are seeking food assistance, which pantry is closest, whether or not they need a referral to receive aid, and times, dates and locations. The database could also screen clients to see what government assistance they qualify for and what benefits they already receive. A database would also be useful in conducting future research projects and for food-related grant proposals for hunger organizations. If all counties are striving for the same goal, they can construct mission statements and plan events on a similar time scale. 
Without a public transportation system or local access to adequate grocers, counties such as Clay and Webster will struggle to meet the food needs of their communities. All of the organizations in the food sector must work collectively towards the goal of addressing hunger in West Virginia. Until a common ground is realized, areas with the most available resources will continue to thrive, while food deserts suffer.

\section{Future Research}

There is considerable room for future research on the subject of hunger in West Virginia. Studies such as this could be replicated to capture all 55 counties in the state in order to gather more generalized statistics. Not all counties are limited in regards to food access, and they should reflect this in future research by projecting different types of problems or threats.

As stated earlier, the hunger relief sector could benefit from a gap analysis study to gather statistics about specific communities and counties that have service gaps in the food sector. A study of this nature could be done based on regional or congressional districts. Government agencies, local and state planning commissions, food banks, and food providers would be able to use this information to target underserved or unserved communities in West Virginia. 


\section{References}

1. Anderson, Molly and John Cook. "Community Food Security: Practice in Need of Theory?”, Agriculture and Human Values”, 1999, Vol. 16, pg. 141-150.

2. Alaimo, Katherine, Ronette Briefel, Edward Frongillo, and Christine Olson. "Food Insufficiency Exists in the United States”, American Journal of Public Health, March 1998, Vol. 88, No.3, pg. 419-426.

3. Alaimo, Katherine, C.M. Olsen, and E. Frongillo. "Family Food Insufficiency, Family Income, and Health in U.S. preschool-aged Children” American Journal of Public Health, 2001, No. 91, pg. 781-786.

4. American Community Survey 2008. U.S. Census Bureau, www.census.gov/acs/www/.

5. Appalachian Regional Commission, County Economic Status in Appalachia, Fiscal Year 2010. U.S. Bureau of Labor Statistics, October 2009, ww.arc.gov.

6. Bartfield, Judi and Rachel Dunifon. "State-Level Predictors of Food Insecurity among Households with Children”, Journal of Policy Analysis and Management, 2006, Vol. 25, No. 4, pg. 921-42.

7. Bureau of Labor Statistics. United States Department of Labor. 2010, www.bls.gov.

8. Blanchard, Troy C. and Thomas A. Lyson. "Retail Concentration, Food Deserts, and Food Disadvantaged Communities in Rural America. 2006.

9. Blanchard, Troy C. and Thomas A. Lyson. "Access to Low Cost Groceries in Nonmetropolitan Counties: Large Retailers and the Creation of Food Deserts”, 2002, http://srdc.msstate.edu/measuring/blanchard.pdf.

10. Bureau of Business and Economic Research, West Virginia University. "2008 West Virginia County Data Profile: Clay County”, 2008, www.bber.wvu.edu.

11. Bureau of Business and Economic Research, West Virginia University. "2008 West Virginia County Data Profile: Webster County”, 2008, www.bber.wvu.edu

12. Campbell, C. "Food Insecurity: A Nutritional Outcome or a Predictable Variable", Journal of Nutrition. Symposium: Nutritional Assessment and Intervention 1991 121:408-15.

13. Castellano, Rebecca. "Learning from the Past to Improve the Future: Best Practices and Healthy Food Access in Ohio", June 2010, Ohio Department of Agriculture.

14. Cohen, Rhonda, James Mabli, Frank Potter and Zhanyun Zhao. 2010. "Hunger in America 2010: National Report Prepared for Feeding America”, March 2010, www.hungerinamerica.org.

15. Daponte, B., G. Lewis, S. Sanders, and L. Taylor. "Food Pantry Use Among Low-Income Households in Allegheny County, Pennsylvania”, Journal of Nutrition Education, 1998, Vol. 30, No. 1, pg. 57-63.

16. Duffy, Patricia A., Marina Irimia-Vladu, Suzie Cashwell, John P. Bartkowski, Joseph J. Molnar, and Vanessa Casanova. "Food Pantries and the Populations They Serve: Strange Bedfellows or Strategic Partners?”, Sociological Inquiry, Vol. 76, No. 4, November 2006, 502-527.

17. Edlefsen, Miriam S. and Christine M. Olson. "Perspectives of Volunteers in Emergency Feeding Programs on Hunger, Its Causes, and Solutions", Journal of Nutrition and Educational Behavior, 2002, 34:93-99.

18. Guy, C.M. and G. David. "Measuring Physical Access to Healthy Foods in Areas of Social Deprivation”, International Journal of Consumer Studies, 2004, Vol. 28, pg. 222234.

19. Harper, Aletha, Annie Shattuck, Eric Holt-Gimenez, Alison Alkon and Frances Lambrick. "Food Policy Councils: Lessons Learned”, Institute for Food and Development Policy, 2009. 
20. Kantor, Linda. “Community Food Security Programs Improve Food Access”, Food Review, 2001, Volume 24, Issue 1, pg. 20-26.

21. Kaufman, Phil R. "Rural Poor Have Less Access to Supermarkets, Large Grocery Stores”, Rural Development Perspectives, Vol. 13, No. 3, pg. 19-26.

22. Kleinman, Ronald, Michael Murphy, Michelle Little, Maria Pagano, Cheryl Wehler, Kenneth Regal and Michael Jellinek. "Hunger in Children in the United States: Potential Behavioral and Emotional Correlates", Pediatrics: Journal of the American Academy of Pediatrics, January 1998, Vol. 101, No. 1, 1-6.

23. Lichter, Daniel T. and Lori Ann Campbell. "Changing Patterns of Poverty and Spatial Inequality in Appalachia”, Appalachian Regional Commission, April 2005, www.arc.gov.

24. Mooney, C. "Cost and the Availability of Healthy Food Choices in a London Health District”, Journal of Human Nutrition, 1986, Vol. 86, pg. 1684-93.

25. Morland, Kimberly, Steve Wing, Ana Diez Roux, and Charles Poole. "Neighborhood Characteristics Associated with the Location of Food Stores and Food Service Places", American Journal of Preventative Medicine, 2001, Vol. 22, Number 1, pg. 23-29.

26. Morton, Lois Wright and Troy Blanchard. "Starved for Access: Life in Rural America's Food Deserts”, Rural Sociological Society, Rural Realities, 2007, Vol. 1, Issue 4, pg. 110.

27. Morton, Lois Wright, Ella Bitto, Mary Oakland, and Mary Sand. "Solving the Problems of Iowa Food Deserts: Food Insecurity and Civic Structure”, Rural Sociology, 2005, pg. 94-112.

28. Nord, Mark and Margaret Andrews. "Putting Food on the Table: Household Food Security in the United States”, Amber Waves, February 2003, USDA ERS, Service, www.ers.usda.gov/AmberWaves/Feb03/Features/PuttingFood.htm.

29. Nord, Mark, Margaret Andrews, and Steven Carlson. "Measuring Food Security in the United States: Household Food Security in the United States, 2007”, USDA Economic Research Service, ERR-66. November 2008.

30. Ohls, J. and F. Saleem-Ismail. "The Emergency Food Assistance System: Findings From the Provider Survey, Volume 1: Executive Summary”, 2002, FANRR-16-1, USDA, Economic Research Service.

31. Ohls, J., F. Saleem-Ismail, R. Cohen, and B. Cox. "The Emergency Food Assistance System Study: Findings from the Provider Survey”, 2002, Volume II: Final Report Mathematica Policy Research.

32. Poppendieck, Janet. "Want Amid Plenty: From Hunger to Inequality”, Monthly Review, 1998, Vol. 50, No.3, pg. 125-136.

33. Singh, G., M. Logan, and P. Van Dyck. "A Multilevel Analysis of State and Regional Disparities in Childhood and Adolescent Obesity in the U.S.”, Journal of Community Health, 2008, Vol. 33, pg. 90-102.

34. Schafft, Kai A., Eric B. Jensen, and C. Clare Hinrichs. "Food Deserts and Overweight Schoolchildren: Evidence from Pennsylvania”, Rural Sociology, 2009, Vol. 74, pg. 153177

35. Townsend, M.S., J. Peerson, B. Love, C. Achterberg, and C. Murphy. "Food Insecurity is Positively Related to Overweight in Women”, Journal of Nutrition, 2001, Vol. 131, pg. 1738-1745.

36. U.S. Census 2000. www.census.gov/census2000/states/wv.html.

37. Webber, Melissa. "Relationships Between Food Insecurity and Overweight in PreschoolAged Children in Rural West Virginia", College of Agriculture, Forestry, and Consumer Sciences, West Virginia University, 2007, www.wvuscholar.wvu.edu:8881//exlibris/dtl/d3_1/apache_media/13682.pdf.

38. White, M., “Food Access and Obesity”, Obesity Reviews, 2007, Volume 8, Suppl. 1, pg. 99-107 
39. Williams, K.J., C. Taylor, K. Wolf, R. Lawson and R. Crespo. "Cultural Perceptions of Healthy Weight in Rural Appalachian Youth”, Rural and Remote Health, 2008, Vol. 8, pg. 932, www.rrh.org.au.

40. Wolfe, Wendy S. , Edward A. Frongillo and Pascale Valois. "Understanding the Experience of Food Insecurity by Elders Suggests Ways to Improve Its Measurement", The Journal of Nutrition, 2003, 133: 2762-2769. 


\section{Appendix 1}

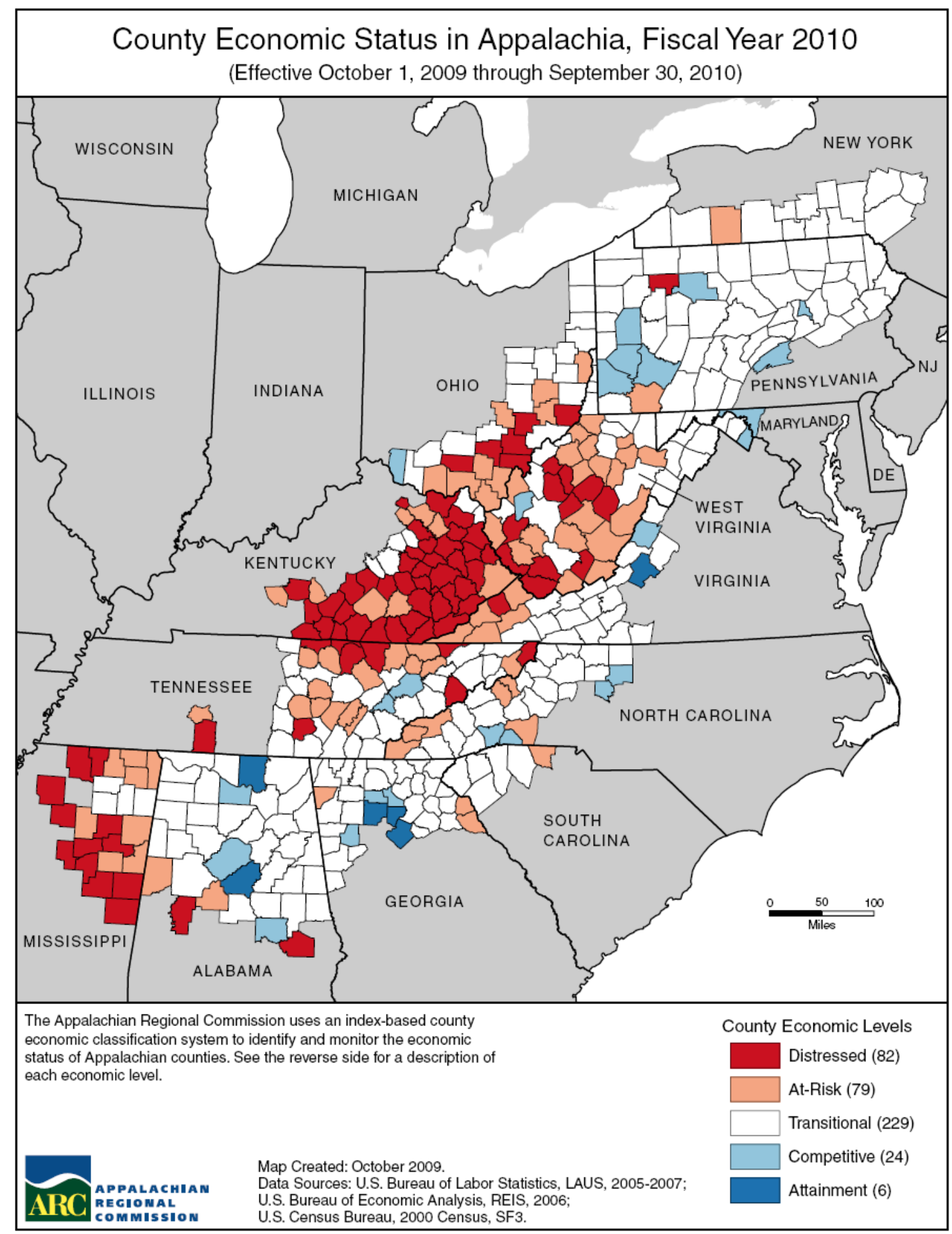




\section{County Economic Status Classification System, FY 2010}

The Appalachian Regional Commission (ARC) uses an index-based county economic classification system to identify and monitor the economic status of Appalachian counties. The system involves the creation of a national index of county economic status through a comparison of each county's averages for three economic indicators - three-year average unemployment rate, per capita market income, and poverty rate-with national averages. The resulting values are summed and averaged to create a composite index value for each county. Each county in the nation is then ranked, based on its composite index value, with higher values indicating higher levels of distress.

\section{County Economic Levels}

Each Appalachian county is classified into one of five economic status designations, based on its position in the national ranking.

\section{Distressed}

Distressed counties are the most economically depressed counties. They rank in the worst 10 percent of the nation's counties

\section{At-Risk}

At-Risk counties are those at risk of becoming economically distressed. They rank between the worst 10 percent and 25 percent of the nation's counties.

\section{Transitional}

Transitional counties are those transitioning between strong and weak economies. They make up the largest economic status designation. Transitional counties rank between the worst 25 percent and the best 25 percent of the nation's counties.

\section{Competitive}

Competitive counties are those that are able to compete in the national economy but are not in the highest 10 percent of the nation's counties. Counties ranking between the best 10 percent and 25 percent of the nation's counties are classified competitive.

\section{Attainment}

Attainment counties are the economically strongest counties. Counties ranking in the best 10 percent of the nation's counties are classified attainment

\section{ARC County Economic Status Designation by National Index Value Rank}

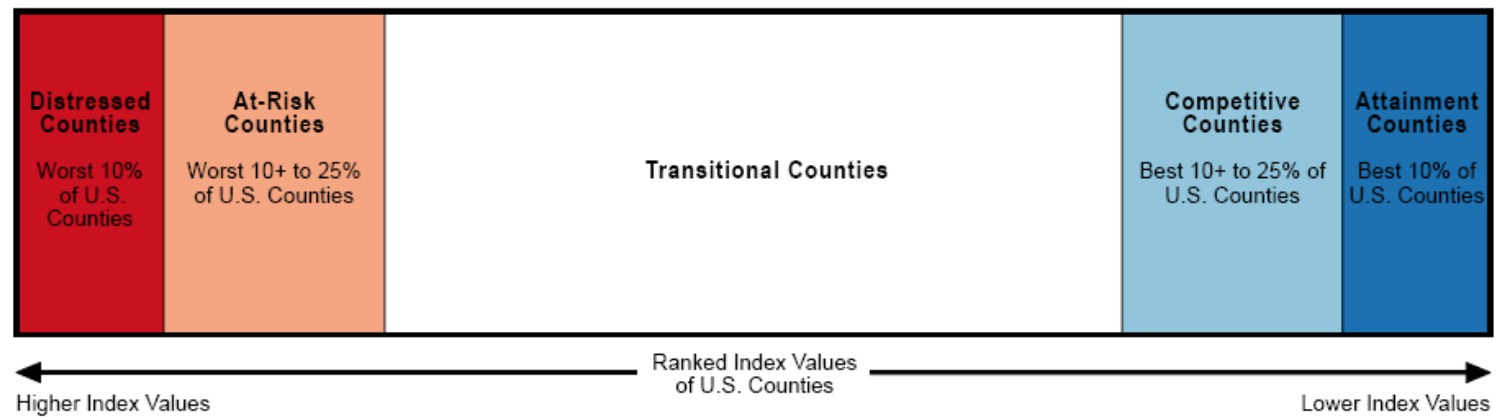




\section{Appendix 2}

\section{AGENCY SURVEY}

\section{Program Types}

Please refer to the following definitions when responding to this questionnaire.

Food pantries are programs that distribute groceries (non-prepared foods) and other basic supplies for off-site use, usually for preparation in the client's residence. An agency that receives boxed food from the food bank to distribute to their client's qualifies as a food pantry. Agencies that purchase or receive food from other sources than a food bank, yet still distribute groceries to clients for off-site use qualify as a food pantry. An agency that does not directly distribute food to clients is excluded from the pantry category. This category includes the Backpack program.

Emergency Kitchen, also referred to as a soup kitchen or community kitchen, is a program that provides prepared meals on-site to clients in need who do not reside on the agency's premises. An emergency kitchen may also distribute prepared meals for clients to take off-site, such as brown bag lunches for weekend consumption when the kitchen is closed.

Emergency Shelter is a program that provides shelter services and serves one or more meals a day on a short-term basis to low-income clients in need. The length of stay will vary. The actual length of residence is less important than the nature of the service. Shelter may be the primary or secondary purpose of the service. Examples include shelters for the homeless, shelters with substance abuse programs, and transitional shelters such as shelters for battered women fit in this group. Residential programs that provide services to the same clients for extended periods, however, should not be categorized as shelters. Other examples of programs that should not be categorized as shelters are mental/health group homes or juvenile probation group homes.

Other programs are any programs that have a primary purpose other than emergency food distribution. Examples: day care programs, senior feeding programs, or summer camps. This category excludes food pantries, emergency kitchens, and emergency shelters.

\section{MARKING DIRECTIONS}

- Please print legibly.

- When entering numbers, please enter whole numbers only. Do not enter fractions or decimals.

- For the ovals, make a heavy dark mark that completely fills the oval.

- To change a written response, you may use white liquid correction fluid. For the ovals, place an " $X$ " through the first mark and mark the oval for your preferred response. 


\section{Your Agency's Services}

This study involves many different types of agencies who use various terms to describe their services. Please refer to the definitions on the previous page before continuing.

1. Please record the total number of pantries, kitchens, shelters, and other programs you currently operate.

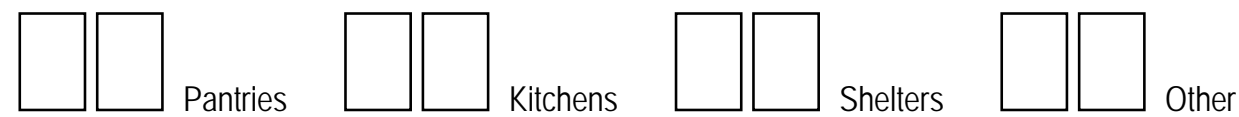

2. Please list below the names and ZIP codes of your programs as described on the previous page. Please list the programs in ZIP Code order.

Special Instructions

- If a program operates at two locations, list it twice with its different ZIP Codes noted.

- If there are more than three programs in a category, list 3 programs you judge to be typical and their ZIP Codes.

IMPORTANT: For the remainder of the questionnaire, if you operate one program or any type, always answer about that program; if you operate two programs of any type, always answer about the first program of each type; and if you operate three programs of any type, always answer about the first program of each type. These will be referred to as the "selected programs." Circle the number of the "selected programs" and mark the numbers in Question $3 a$.

Pantries- Circle the number of the selected program.

\begin{tabular}{|l|c|c|}
\hline Name of Program & ZIP Code of Program & $\begin{array}{c}\text { Program } \\
\text { Number }\end{array}$ \\
\hline & & P1 \\
\hline & & P2 \\
\hline
\end{tabular}

Kitchens- Circle the number of the selected program.

\begin{tabular}{|l|l|c|}
\hline Name of Program & ZIP Code of Program & $\begin{array}{c}\text { Program } \\
\text { Number }\end{array}$ \\
\hline & & $\mathrm{K} 1$ \\
\hline & & $\mathrm{K} 2$ \\
\hline & & $\mathrm{K} 3$ \\
\hline
\end{tabular}


Shelters- Circle the number of the selected program.

\begin{tabular}{|l|c|c|}
\hline Name of Program & ZIP Code of Program & $\begin{array}{c}\text { Program } \\
\text { Number }\end{array}$ \\
\hline & & $\mathrm{S} 1$ \\
\hline & & $\mathrm{S} 2$ \\
\hline & & $\mathrm{S} 3$ \\
\hline
\end{tabular}

Other programs- Circle the number of the selected program.

\begin{tabular}{|l|l|c|}
\hline Name of Program & ZIP Code of Program & $\begin{array}{c}\text { Program } \\
\text { Number }\end{array}$ \\
\hline & & 01 \\
\hline & & 02 \\
\hline & & 03 \\
\hline
\end{tabular}

3a. Circle the numbers of the selected programs (see Page 2).

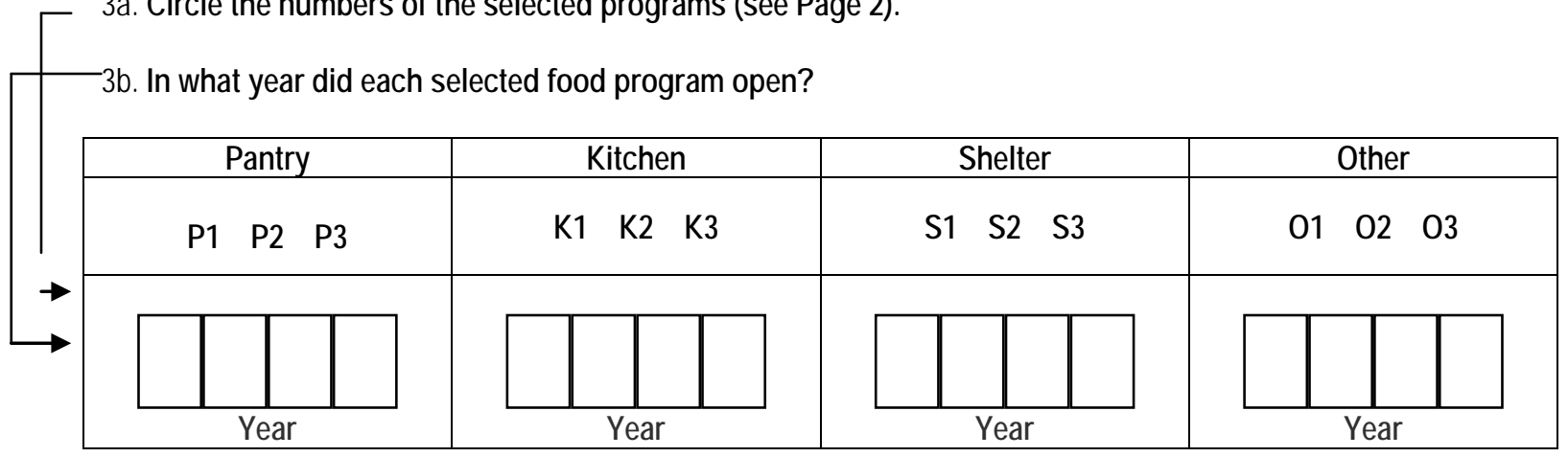

THE REMAINING QUESTIONS REFER TO THE SELECTED PROGRAMS THAT ARE MARKED IN QUESTION 3a. 
4. For each selected program, please indicate which of the following services, if any, are currently being provided. Mark all that apply for each program.

\begin{tabular}{|c|c|c|c|c|}
\hline & Pantry & Kitchen & Shelter & $\begin{array}{l}\text { Other } \\
\text { Program }\end{array}$ \\
\hline \multicolumn{5}{|l|}{ FOOD RELATED SUPPORT } \\
\hline Nutrition counseling & $\square$ & $\square$ & $\square$ & $\square$ \\
\hline Eligibility counseling for WIC & $\square$ & $\square$ & $\square$ & $\square$ \\
\hline Eligibility counseling for Food Stamps & $\square$ & $\square$ & $\square$ & $\square$ \\
\hline \multicolumn{5}{|l|}{ OTHER CLIENT TRAINING } \\
\hline Employment training & $\square$ & $\square$ & $\square$ & $\square$ \\
\hline Retraining physically disabled & $\square$ & $\square$ & $\square$ & $\square$ \\
\hline Retraining mentally ill/challenged & $\square$ & $\square$ & $\square$ & $\square$ \\
\hline Legal Services/Tax Preparation & $\square$ & $\square$ & $\square$ & $\square$ \\
\hline Utility Bill Assistance & $\square$ & $\square$ & $\square$ & $\square$ \\
\hline Short Term Financial Assistance & $\square$ & $\square$ & $\square$ & $\square$ \\
\hline $\begin{array}{l}\text { Budget/Credit counseling or Consumer } \\
\text { Protection }\end{array}$ & $\square$ & $\square$ & $\square$ & $\square$ \\
\hline \multicolumn{5}{|l|}{ OTHER CLIENT DIRECT SERVICES } \\
\hline Health services and health clinics & $\square$ & $\square$ & $\square$ & $\square$ \\
\hline Transportation & $\square$ & $\square$ & $\square$ & $\square$ \\
\hline Clothing/Furniture & $\square$ & $\square$ & $\square$ & $\square$ \\
\hline Subsidized housing assistance & $\square$ & $\square$ & $\square$ & $\square$ \\
\hline Housing rehabilitation & $\square$ & $\square$ & $\square$ & $\square$ \\
\hline Supported employment (job training) & $\square$ & $\square$ & $\square$ & $\square$ \\
\hline Senior Programs & $\square$ & $\square$ & $\square$ & $\square$ \\
\hline Soup kitchen meals & $\square$ & & $\square$ & $\square$ \\
\hline Food pantry bags & & $\square$ & $\square$ & $\square$ \\
\hline $\begin{array}{c}\text { THIS PROGRAM PROVIDES NONE OF } \\
\text { THE SERVICES LIST ABOVE }\end{array}$ & $\square$ & $\square$ & $\square$ & $\square$ \\
\hline
\end{tabular}




\section{Services Levels}

5. During the past year, that is between January 1, 2009 and December 31, 2009, approximately how many different people or different households were served by the food program of each selected program? Please provide your best estimate. RECORD BELOW.

Example: During the past year one program served meals to 25 people who came in every day. Another 50 people came to the program two times during the month and another 25 came only once a month. The number of different people is $100(25+50+25)$. The number of times each person came in a month or week does not matter.

\begin{tabular}{|c|c|c|c|c|}
\hline & Pantry & Kitchen & Shelter & Other Programs \\
\hline $\begin{array}{c}\text { Number of different } \\
\text { people served }\end{array}$ & & $\square$ & & \\
\hline Don't Know & & & $\square$ & $\square$ \\
\hline $\begin{array}{c}\text { Number of different } \\
\text { households served }\end{array}$ & $\square$ & & & \\
\hline Don't Know & $\square$ & & \\
\hline
\end{tabular}

6. During a typical week, approximately how many meals are served and/or bags or boxes of food distributed by each of the selected programs? Please provide your best estimate. RECORD BELOW.

\begin{tabular}{|c|c|c|c|c|}
\hline & Pantry & Kitchen & Shelter & Other Programs \\
\hline $\begin{array}{c}\text { Total Number of bags or boxes of food } \\
\text { distributed per week }\end{array}$ & & & & \\
\hline Don't Know & $\square$ & & & \\
\hline Total number of meals served per week & & & & $\square$ \\
\hline Don't Know & & $\square$ & $\square$ & $\square$ \\
\hline
\end{tabular}

6a. How much does a typical bag or box usually weigh? Your best estimate is fine. RECORD BELOW.

\begin{tabular}{|c|c|c|c|c|}
\hline & Pantry & Kitchen & Shelters & Other Programs \\
\hline $\begin{array}{c}\text { Weight of a typical } \\
\text { bag or box }\end{array}$ & Ibs. & & & \\
\hline Don't Know & $\square$ & & & \\
\hline
\end{tabular}


6b. On what date was each of the selected programs most recently open before today?

\begin{tabular}{|c|c|c|c|c|}
\hline & Pantry & Kitchen & Shelter & Other Programs \\
\hline $\begin{array}{c}\text { Most recent date } \\
\text { open (M/D/YR) } \\
\text { before today }\end{array}$ & $\square$ & $\square$ & $\square$ & \\
\hline Don't Know & $\square$ & $\square$ \\
\hline
\end{tabular}

6c. On that date recorded in Question $6 \mathrm{~b}$, how many different persons or households did your program serve? And how many meals were served or bags or boxes of food distributed by each of the selected programs on that day? Please provide your best estimate. RECORD BELOW.

\begin{tabular}{|c|c|c|c|c|}
\hline & Pantry & Kitchen & Shelter & Other Programs \\
\hline $\begin{array}{c}\text { Number of different } \\
\text { people served }\end{array}$ & & & & \\
\hline Don't Know & & $\square$ & $\square$ & $\square$ \\
\hline $\begin{array}{c}\text { Number of different } \\
\text { households served }\end{array}$ & $\square$ & & & \\
\hline Don't Know & $\square$ & & & \\
\hline $\begin{array}{c}\text { Number of bags or } \\
\text { boxes distributed }\end{array}$ & & & & \\
\hline Don't Know & & & & \\
\hline $\begin{array}{c}\text { Number of meals } \\
\text { served }\end{array}$ & & & & $\square$ \\
\hline Don't Know & & & & \\
\hline
\end{tabular}

7a. Compared to 3 years ago, that is 2007 , is this program providing food to.....

\begin{tabular}{|c|c|c|c|c|}
\hline & Pantry & Kitchen & Shelter & Other Program \\
\hline More Clients? & $\square$ & $\square$ & $\square$ & $\square$ \\
\hline Fewer Clients? & $\square$ & $\square$ & $\square$ & $\square$ \\
\hline About the same? & $\square$ & $\square$ & $\square$ & $\square$ \\
\hline $\begin{array}{c}\text { Don't Know } \\
\text { in 2007 }\end{array}$ & $\square$ & $\square$ & $\square$ & $\square$ \\
\hline \begin{tabular}{c} 
Program did not exist \\
\hline
\end{tabular} & $\square$ & $\square$ & $\square$ & $\square$ \\
\hline
\end{tabular}


8. For each selected program, approximately what percent of the distributed food comes from your food bank?

\begin{tabular}{|c|c|c|c|}
\hline Pantry & Kitchen & Shelter & Other Program \\
\hline \% From Food Bank & $\longleftarrow$ \% From Food Bank & — ${ }^{-}$From Food Bank & \% From Food Bank \\
\hline
\end{tabular}

8a. Do the selected programs distribute government or USDA commodities that you receive through your food bank or state agency? Please mark yes or no for each program.

Note: Government/USDA commodities include USDA-distributed food provided through programs like the Temporary Emergency Food Assistance Program (TEFAP) or Commodity Supplemental Food Program.

\begin{tabular}{|c|c|c|c|c|}
\hline & Pantry & Kitchen & Shelter & $\begin{array}{c}\text { Other } \\
\text { Program }\end{array}$ \\
\hline Yes & $\square$ & $\square$ & $\square$ & $\square$ \\
\hline No & $\square$ & $\square$ & $\square$ & $\square$ \\
\hline Don't Know & $\square$ & $\square$ & $\square$ & $\square$ \\
\hline
\end{tabular}

8b. Please indicate which of the following are other sources of food for each selected program. Please mark all that apply.

\begin{tabular}{|c|c|c|c|c|}
\hline & Pantry & Kitchen & Shelter & Other Programs \\
\hline $\begin{array}{c}\text { Church or religious } \\
\text { congregations }\end{array}$ & $\square$ & $\square$ & $\square$ & $\square$ \\
\hline $\begin{array}{c}\text { Local merchant or farmer } \\
\text { donations }\end{array}$ & $\square$ & $\square$ & $\square$ & $\square$ \\
\hline Local food drives & $\square$ & $\square$ & $\square$ & $\square$ \\
\hline Food purchased by agency & $\square$ & $\square$ & $\square$ & $\square$ \\
\hline Other (Please write in) & $\square$ & $\square$ & $\square$ & $\square$ \\
\hline
\end{tabular}


9. During the past year, that is between January 1, 2009 and December 31, 2009, did the selected programs turn away any clients for any reason? Please mark only one for each selected program.

\begin{tabular}{|c|c|c|c|c|}
\hline & Pantry & Kitchen & Shelter & Other Program \\
\hline Turned away clients & $\square$ & $\square$ & $\square$ & $\square$ \\
\hline Did not turn away clients & $\square$ & $\square$ & $\square$ & $\square$ \\
\hline Don't Know & $\square$ & $\square$ & $\square$ & $\square$ \\
\hline
\end{tabular}

FOR EACH PROGRAM MARKED “TURNED AWAY CLIENTS" IN Q.9, GO TO Q. 10 BELOW.

FOR EACH PROGRAM MARKED "DID NOT TURN AWAY CLIENTS" OR "DON'T KNOW" IN Q. 9, SKIP TO Q 13.

10. (FOR EACH PROGRAM THAT TURNED AWAY CLIENTS IN Q.9) For which of the following reasons did each selected program turn clients away? Mark all that apply.

\begin{tabular}{|c|c|c|c|c|c|}
\hline $\begin{array}{c}\text { Item } \\
\text { Number }\end{array}$ & Pantry & Kitchen & Shelter & Other Program \\
\hline 1 & A lack of food or resources & $\square$ & $\square$ & $\square$ & $\square$ \\
\hline 2 & $\begin{array}{c}\text { Services needed not provided } \\
\text { by the program }\end{array}$ & $\square$ & $\square$ & $\square$ & $\square$ \\
\hline 3 & $\begin{array}{c}\text { Clients were ineligible or could } \\
\text { not prove eligibility }\end{array}$ & $\square$ & $\square$ & $\square$ & $\square$ \\
\hline 4 & $\begin{array}{c}\text { Clients came more often than } \\
\text { program rules allow }\end{array}$ & $\square$ & $\square$ & $\square$ & $\square$ \\
\hline 5 & $\begin{array}{c}\text { Clients exhibited drug, alcohol, } \\
\text { or behavior problem }\end{array}$ & $\square$ & $\square$ & $\square$ & $\square$ \\
\hline 6 & $\begin{array}{c}\text { Clients lived outside service } \\
\text { area }\end{array}$ & $\square$ & $\square$ & $\square$ & $\square$ \\
\hline 7 & $\begin{array}{c}\text { Clients did not have ID } \\
\text { required by program }\end{array}$ & $\square$ & $\square$ & $\square$ & $\square$ \\
\hline 8 & $\begin{array}{c}\text { Client's income exceeded } \\
\text { program guidelines }\end{array}$ & $\square$ & $\square$ & $\square$ & $\square$ \\
\hline 9 & $\begin{array}{c}\text { Other (Please write in) } \\
\text { r }\end{array}$ & $\square$ & $\square$ & $\square$ & $\square$ \\
\hline
\end{tabular}


11. (FOR EACH PROGRAM WITH REASONS CHECKED Q. 10) Please record the item numbers of the MOST FREQUENT reason from $Q .10$ for turning away clients.

\begin{tabular}{|c|l|l|l|l|}
\hline & Pantry & Kitchen & Shelter & Other Program \\
\hline Most Frequent Reason & & & & \\
\hline $\begin{array}{c}\text { Second Most Frequent } \\
\text { Reason }\end{array}$ & & & & \\
\hline
\end{tabular}

12. During the past year, that is between January 1, 2009 and December 31, 2009, approximately how many clients did each selected program turn away?

\begin{tabular}{|c|c|c|c|c|}
\hline $\begin{array}{c}\text { Total number of clients } \\
\text { turned away }\end{array}$ & Pantry & Kitchen & Shelter & Other Programs \\
\hline Don't Know & $\square$ & $\square$ & $\square$ & \\
\hline
\end{tabular}

13. During the past year, that is January 1, 2009 and December 31, 2009, about how often did each of the selected programs have to reduce meal portions or reduce the quantity of food in food packages because of a lack of food. Please mark only one for each selected program.

\begin{tabular}{|c|c|c|c|c|}
\hline & Pantry & Kitchen & Shelter & Other Programs \\
\hline Never & $\square$ & $\square$ & $\square$ & $\square$ \\
\hline Rarely & $\square$ & $\square$ & $\square$ & $\square$ \\
\hline 1-3 Times a Month & $\square$ & $\square$ & $\square$ & $\square$ \\
\hline 4-6 Times a Month & $\square$ & $\square$ & $\square$ & $\square$ \\
\hline 7-10 Times a Month & $\square$ & $\square$ & $\square$ & $\square$ \\
\hline Over 10 Times a Month & $\square$ & $\square$ & $\square$ & $\square$ \\
\hline Always & $\square$ & $\square$ & $\square$ & $\square$ \\
\hline
\end{tabular}


14. In your opinion, during a typical week, how much more food, if any, does each of the selected programs need in order to adequately meet their demand for food? Your best estimate is fine. RECORD BELOW.

\begin{tabular}{|c|c|c|c|c|}
\hline & Pantry & Kitchen & Shelter & $\begin{array}{c}\text { Other } \\
\text { Programs }\end{array}$ \\
\hline NONE (No more food is needed) & $\square$ & $\square$ & $\square$ & $\square$ \\
\hline $\begin{array}{c}\text { More food is needed (Write in number of } \\
\text { pounds per week) }\end{array}$ & & & & \\
\hline $\begin{array}{c}\text { More food is needed (Write in number of } \\
\text { meals per week) }\end{array}$ & $\square$ & $\square$ & $\square$ & $\square$ \\
\hline Don't Know & $\square$ & & \\
\hline
\end{tabular}

15. Currently, how many paid staff is employed by the selected programs?

\begin{tabular}{|l|l|l|l|l|}
\hline & Pantry & Kitchen & Shelter & Other Programs \\
\hline Number of Paid Staff & & & & \\
\hline
\end{tabular}

16. During the past week: Record Below

\begin{tabular}{|c|l|l|l|l|}
\hline & Pantry & Kitchen & Shelter & $\begin{array}{c}\text { Other } \\
\text { Programs }\end{array}$ \\
\hline $\begin{array}{c}\text { How many different volunteers assisted } \\
\text { with the work of each selected program } \\
\text { in the last week? }\end{array}$ & & & & \\
\hline $\begin{array}{c}\text { In total, how many volunteered hours } \\
\text { did each selected program receive last } \\
\text { week? }\end{array}$ & & & & \\
\hline
\end{tabular}

17. Mark which of the following problems threatens the continued operation of each selected program. Mark all apply.

\begin{tabular}{|c|c|c|c|c|}
\hline & Pantry & Kitchen & Shelter & Other Programs \\
\hline Problems related to funding & $\square$ & $\square$ & $\square$ & $\square$ \\
\hline Problems related to food supplies & $\square$ & $\square$ & $\square$ & $\square$ \\
\hline $\begin{array}{c}\text { Problems related to paid staff or } \\
\text { personnel }\end{array}$ & $\square$ & $\square$ & $\square$ & $\square$ \\
\hline $\begin{array}{c}\text { Problems related to volunteers } \\
\text { Community Resistance }\end{array}$ & $\square$ & $\square$ & $\square$ & $\square$ \\
\hline $\begin{array}{c}\text { Other } \\
\text { (Please write in)__ }\end{array}$ & $\square$ & $\square$ & $\square$ & $\square$ \\
\hline $\begin{array}{c}\text { CONTINUED OPERATION NOT } \\
\text { THREATENED BY ANY PROBLEM }\end{array}$ & $\square$ & $\square$ & $\square$ & $\square$ \\
\hline
\end{tabular}




\section{Questions About Other Programs And Your Agency}

18. If the food supply you receive from your food bank were eliminated, how much of an impact would this have on your program?

\begin{tabular}{|c|c|c|c|c|}
\hline & Pantry & Kitchen & Shelter & $\begin{array}{c}\text { Other } \\
\text { Programs }\end{array}$ \\
\hline No impact at all & $\square$ & $\square$ & $\square$ & $\square$ \\
\hline Minimal impact & $\square$ & $\square$ & $\square$ & $\square$ \\
\hline Significant impact & $\square$ & $\square$ & $\square$ & $\square$ \\
\hline Devastating impact & $\square$ & $\square$ & $\square$ & $\square$ \\
\hline Unsure, we have no idea & $\square$ & $\square$ & $\square$ & $\square$ \\
\hline
\end{tabular}

19. Please indicate which of the following programs or facilities your agency operates. Mark all that apply.

\begin{tabular}{|c|c|c|c|}
\hline Health Clinic & $\square$ & $\begin{array}{c}\text { Group Home for physically/mentally } \\
\text { disadvantaged }\end{array}$ & $\square$ \\
\hline Senior congregate feeding program & $\square$ & Youth after school program & $\square$ \\
\hline Other residential facility & $\square$ & Child Day Care program & $\square$ \\
\hline Other (Please write in) & $\square$ & No Other Programs & $\square$ \\
\hline
\end{tabular}

20. Is your agency:

MARK ONE ONLY

\begin{tabular}{|c|c|}
\hline Faith based or religious affiliated nonprofit & $\square$ \\
\hline Other private nonprofit & $\square$ \\
\hline Governmental & $\square$ \\
\hline Community Action Program & $\square$ \\
\hline Other (Please write in & $\square$ \\
\hline
\end{tabular}

TURN TO NEXT PAGE FOR INSTRUCTIONS ON HOW TO RETURN THE QUESTIONNAIRE. 
Thank you for completing this questionnaire. Your responses have made an important contribution to the overall success of this study.

Use the envelope provided to return the questionnaire.

If you have misplaced the envelope, please send the completed survey to:

\section{Chad Morrison \\ 11 Meadow Lane \\ Sutton, WV 26601}

If you have any questions, contact me at 304-880-3205 or 304-765-5542.

\footnotetext{
John H. $\mathrm{H}$. VN.cn=John H. Hagen, $0=W$
Virginia University Libraries,
ou=Acquisitions Departme HOG
} 